\title{
Adeus à classe trabalhadora?
}

Farewell to the Working Class? ${ }^{1}$

\author{
Geoff Eley* \\ Keith Nield (in memoriam) ${ }^{\star *}$ \\ Tradução: Luís Marcos Sander
}

\section{Resumo}

No início da década de 1980, a política centrada em classes da tradição socialista estava em crise, e comentadores importantes adotaram tons apocalípticos. No final da década, a esquerda permanecia profundamente dividida entre os advogados da mudança e os defensores da fé. Em meados dos anos 1990, os primeiros tinham, de modo geral, ganhado a batalha. $\mathrm{O}$ artigo busca apresentar essa mudança contemporânea não como a 'morte da classe', mas como o desaparecimento de um tipo particular de sociedade de classes, marcado pelo processo de formação da classe trabalhadora entre os anos 1880 e 1940 e pelo alinhamento político daí resultante, atingindo seu apogeu na construção social-democrata do acordo do pós-guerra. Quando mudanças de longo prazo na economia se combinaram com o ataque ao keynesianismo na política de recessão a partir de meados da década de 1970, a unidade da classe trabalhadora deixou de estar disponível da forma antiga e bastante utilizada, como

\section{Abstract}

By the early 1980s, the class-centered politics of the socialist tradition was in crisis. In this situation, leading commentators took apocalyptic tones. By the end of the 1980s, the Left remained deeply divided between the advocates of change and the defenders of the faith. By the mid-1990s the former had mainly carried the day. We wish to present this contemporary transformation not as the 'death of class,' but as the passing of one particular type of class society, one marked by the process of workingclass formation between the 1880s and 1940 s and the resulting political alignment, reaching its apogee in the social democratic construction of the postwar settlement. As long-term changes in the economy combined with the attack on Keynesianism in the politics of recession from the mid-1970s, the unity of the working class ceased to be available in the old and well-tried way, as the natural ground of left-wing politics. While one dominant working-class collectivity went into decline, another

\footnotetext{
* University of Michigan, EUA. ghe@umich.edu

${ }^{\star *}$ Hull University, Reino Unido.
} 
o terreno natural da política de esquerda. Enquanto uma coletividade dominante da classe trabalhadora entrou em declínio, outra se corporificou de modo lento e desigual para tomar o lugar daquela. Mas a unidade operacional dessa nova agregação da classe trabalhadora ainda está, em grande parte, em formação. Para recuperar a eficácia política da tradição socialista, alguma nova visão de agência política coletiva será necessária, uma visão imaginativamente ajustada às condições emergentes da produção e acumulação capitalista no início do século XXI.

Palavras-chave: história social; classe social; identidades. slowly and unevenly materialized to take its place. But the operative unity of this new working-class aggregation - its active agency as an organized political presence - is still very much in formation. To reclaim the political efficacy of the socialist tradition, some new vision of collective political agency will be needed, one imaginatively keyed to the emerging conditions of capitalist production and accumulation at the start of the twenty-first century.

Keywords: social history; social class; identities.

\section{Retratando A ClASSE}

Vamos começar com duas fotografias, cada uma das quais está na sobrecapa de um volume programático. O primeiro livro é Bringing Class Back In: Contemporary and Historical Perspectives [Reintroduzindo a classe: perspectivas contemporâneas e históricas], editado por Scott McNall, Rhonda Levine e Rick Fantasia (Boulder, 1991); o segundo é o volume intitulado Class [Classe], da série Oxford Readers, editado por Patrick Joyce (Oxford, 1995). As imagens evocadas pelo primeiro livro reformaram um conjunto clássico de sentidos numa época em que o termo 'classe' já estava sendo alvo de ataque - não só entre historiadores e historiadoras, mas também na esfera pública mais ampla, à medida que mudanças no universo social da produção solaparam a eficácia de formas de compreensão baseadas no conceito de classe. A primeira fotografia mostra uma multidão de trabalhadores que, claramente, são apresentados como típicos, participando de uma reunião de massas, presumivelmente para uma greve ou algum evento sindical: eles estão animados, são militantes, proletários, trabalhadores manuais, todos homens. A segunda fotografia mostra uma senhora de idade, carrancuda e altiva, olhando para fora da janela de um compartimento de trem britânico de primeira classe: ela é de classe alta, privilegiada e, a julgar pelo chapéu que usa, possivelmente está a caminho de Ascot [local 
de uma corrida de cavalos famosa]. A primeira fotografia exibe a força coletiva da classe trabalhadora, um manifesto visual da agência política baseada na classe, uma corporificação da consciência de classe, uma celebração da massa. A segunda imagem veicula uma ideia muito diferente - não a força coletiva de uma força social organizada, mas a arrogância individualizada do poder, no isolamento esplêndido da riqueza. As duas representações dificilmente poderiam ser mais contrárias. O que está acontecendo?

Numa época de mudanças estruturais massivas no 'mundo real' das classes, em que certezas anteriores estavam começando a se desmantelar (entre meados dos anos 1970 e a década de 1990), certos iconoclastas radicais começaram a sustentar a perda de utilidade, e até a obsolescência, de abordagens baseadas na análise de classe para entender o universo social. Essas discussões também abordaram preocupações centradas em classes da tradição política socialista, que, durante os anos 1980, entrou em sua prolongada crise contemporânea. Os tons eram muitas vezes apocalípticos. "O socialismo está morto", declarou o sociólogo Alain Touraine. "Adeus à classe trabalhadora”, ecoou o teórico social radical André Gorz. ${ }^{2}$ Cambaleando por causa das decepções do final da década de 1970 e dos desastres eleitorais de 1979 e 1983, intelectuais socialistas britânicos também empreenderam um exame completo do pensamento político estabelecido baseado em classes, desde o modelo dado do partido até a suposição automática do "papel principal da classe trabalhadora". ${ }^{3}$ Refletindo sobre a desindustrialização britânica, o radicalismo do ataque de Thatcher ao acordo do pós-guerra e a recomposição da classe trabalhadora, eles concluíram que "o mundo mudou, não apenas em termos incrementais, mas qualitativos”, e que a partir da reestruturação contemporânea um novo tipo de ordem social estava sendo moldado - uma ordem social "caracterizada por diversidade, diferenciação e fragmentação, e não por homogeneidade, padronização e as economias e organizações de escala que caracterizavam a moderna sociedade de massas". ${ }^{4}$

Estamos mais perto agora do que poderia ter produzido as imagens estampadas em nossos dois livros. $O$ poder da agência coletiva dos trabalhadores na primeira fotografia (o ativismo de um sujeito coletivo em busca de mudança, o futuro herdeiro da boa sociedade) é substituído pela imagem puramente individualizada da classe como status - nos espaços físicos protegidos de grande riqueza e privilégio. Além disso, os sentidos desses dois retratos são simbolizados pelo gênero. A ausência completa de mulheres na primeira representação da agência coletiva da classe trabalhadora é substituída pela arrogância da presença feminina na segunda imagem, onde a senhora de idade em questão 
olha malignamente para fora, possivelmente para o tipo de manifestação plebeia retratada pelo livro Bringing Class Back In. Em outras palavras, a classe se expressa pelo gênero masculino onde os trabalhadores exercem a agência, e pelo gênero feminino onde classe significa privilégio, parasitismo e poder calcado no dinheiro. A ação coletiva se defronta com o individualismo egoísta e autocentrado de uma maneira muito familiar.

A imagem da senhora de idade está distante da política e da agência. Trata-se de uma imagem de passividade privilegiada. Na tentativa de retratar as novas valências do conceito de classe, Joyce (ou o capista da editora da Universidade de Oxford) se afasta inteiramente das imagens coletivas, rejeitando arquétipos ou outras representações da massa ou da maioria ordinária dos trabalhadores. Ele também separa a classe incisivamente da ciência econômica e da produção. Com efeito, na seleção de leituras levada a efeito por Joyce há pouco vestígio de trabalhadores em movimento coletivo, organizando-se no local de produção, fazendo greve, mobilizando-se em comunidades, aderindo a partidos socialistas, enfrentando os empregadores ou o Estado. Em vez disso, 'classe' tem a função abstrata e impessoal de uma tradição analítica, uma estrutura discursiva e um termo linguístico. Depois das três primeiras seções que tratam do uso do conceito de classe por parte de teóricos sociais e historiadores, Joyce opta exclusivamente por essa abordagem, encontrando a 'classe' em estruturas dominantes de sentido para além da agência ou do controle popular - em "A história do social”, "A hermenêutica do social”, “A linguagem de classe”. Não há muito sinal de trabalhadores exigindo seus direitos aí.

Esse enquadramento da classe também é surpreendentemente etnocêntrico, omitindo inteiramente questões de diferenças nacionais, império, raça e imigração. Afinal, o pós-modernismo defendido por Joyce rejeita formas mais antigas de análise centrada no conceito de classe ao ver a identidade moldada de outras formas, e, assim, é estranho não encontrar a questão da raça nem a política mais ampla do reconhecimento entre as seleções feitas por ele. Pois não é só o desafio da teoria que desestabiliza noções mais antigas de classe (o aspecto acentuado por Joyce), mas um vigoroso conjunto de histórias sociais contemporâneas também, incluindo a irrupção da 'raça' no próprio centro da política. Numa época em que os mercados de trabalho da Europa ocidental estão se tornando não apenas feminizados, mas visivelmente racializados também, a iconografia consagrada do trabalhador especializado branco do sexo masculino se torna não só a repetição de exclusões antigas, mas uma distorção grave de como a classe trabalhadora está sendo feita atualmente. Em suas 
leituras selecionadas, Joyce não dá acesso a essas questões. Entretanto, Stuart Hall, Paul Gilroy e outros têm insistido em que a identidade britânica - e a 'anglicidade' que está em seu cerne - está estruturada em torno de afirmações vigorosas da diferença racial, parcialmente oriundas do passado colonial e parcialmente das tensões pós-imperiais do declínio da Grã-Bretanha, e tanto um quanto as outras centram a identidade nacional em torno de uma 'brancura' tácita e marginalizam a presença de negros. ${ }^{5} \mathrm{O}$ trabalho feito por David Roediger e outras pessoas vem mudando os parâmetros da história da classe trabalhadora americana nesse tocante. ${ }^{6}$ Aos poucos também estão sendo publicadas monografias sobre a Europa ocidental. ${ }^{7}$

Vamos agora apresentar uma terceira sobrecapa de livro, desta vez de um volume editado por John R. Hall e intitulado Reworking Class [Retrabalhando a classe] (Ithaca, 1997). Neste caso, a capa contém duas litografias, uma inserida na outra. A menor das duas, "Trabalhadoras domésticas", de Claire Mahl Moore (1936), mostra o trabalho penoso pressuposto pela boa vida burguesa, pois duas trabalhadoras humildes esfregam o chão da cozinha contra o pano de fundo de um banquete, e uma terceira pessoa, presumivelmente a dona da casa, observa brutalmente. Isso está sobreposto a uma foto muito maior, "Linha de montagem em época de guerra", de Jolán Gross-Bettelheim (1940), que mostra trabalhadores numa clássica fábrica fordista, provavelmente produzindo munições. Essa imagem mostra o trabalhador de massas das versões mais celebrativas dos 'tempos modernos' (em contraposição a suas distopias), resumido pelos murais de Diego Rivera que estão no Instituto de Artes de Detroit - musculoso, concentrado, aplicado à máquina pesada, marchando em formação, cercado pelo cinza monolítico da fábrica. Esta justaposição é interessante. Ela volta a certas convenções progressistas bem estabelecidas por causa de suas imagens tanto da 'massa' quanto do 'trabalho', mas rompe nossas expectativas de outras formas, pois, em ambas as fotos, os trabalhadores são, todos eles, mulheres.

\section{CRÍticAs FEMINISTAS}

Essas três imagens nos dizem algo sobre o desconforto contemporâneo do conceito de classe. Durante a última década, as críticas feministas das convenções baseadas em gênero da análise de classes vêm produzindo resultados vigorosos. Depois das críticas pioneiras dos anos 1970, o desafio inicial da história das mulheres foi realizado da forma mais eficaz por meio da defesa do gênero como categoria necessária de análise. Em algumas áreas, a análise 
feminista fez um progresso considerável entre a profissão de modo geral, se não em termos quantitativos, certamente em termos do vigor das intervenções centrais. Lembremos, para citar alguns exemplos, a história do pensamento político, um gênero substancial de escrita sobre a classe média americana e britânica do século XIX, o trabalho sobre a cultura popular do final da última parte do século XX e a história das políticas sociais. Na história do trabalho (e em algumas outras áreas como a história da família), entretanto, convenções mais antigas foram mais duradouras. Durante alguns anos, o grande volume de história das mulheres as deixou amplamente intactas. Apenas para tomar um exemplo bem próximo: foi só em 1987, com a controvérsia acadêmica trazida pela publicação de "On Language, Gender, and Working-Class History" [Linguagem, gênero e história da classe trabalhadora], de Joan Scott, que preocupações de gênero, até mesmo entendidas de modo indefinido e pré-teórico (qualquer coisa que implicasse trabalhadoras, divisões de trabalho baseadas em gênero, masculinidade, relações familiares, sexualidades etc.), adentraram o campo de visão do periódico International Labor and Working-Class History, e então principalmente como uma inclusão ocasional de uma perspectiva especificamente baseada em gênero em controvérsias e algumas outras discussões temáticas. ${ }^{8}$ Outro exemplo familiar mais ou menos da mesma época, o livro Working-Class Formation [A formação da classe trabalhadora, 1986], de Ira Katznelson e Aristide Zolberg, de maneira marcante excluiu inteiramente a questão do gênero de suas preocupações, embora algumas contribuições (de Michelle Perrot, Alain Cottereau e Mary Nolan) ocasionalmente percebessem as trabalhadoras. ${ }^{9}$

Já por volta de 1990, entretanto, no volume Perspectives on American Labor History [Perspectivas sobre a história do trabalho nos Estados Unidos, 1989], editado por J. Carroll Moody e Alice Kessler-Harris e que pretendia ser um carro-chefe, dois dos oito ensaios abordavam questões de gênero, "Gender and Labor History" [Gênero e história do trabalho], de Jo Buhle, e "A New Agenda for American Labor History: A Gendered Analysis and the Question of Class" [Uma nova pauta para a história do trabalho nos Estados Unidos: uma análise baseada em gênero e a questão de classe], de Alice Kessler-Harris. ${ }^{10}$ Vários volumes de referência foram publicados na década de 1990, ou estabelecendo coletivamente a centralidade do gênero para o estudo do trabalho e da classe trabalhadora - Work Engendered [Trabalho engendrado, 1991], editado por Ava Baron, ou Gender and Class in Modern Europe [Gênero e classe na Europa moderna, 1996], de Laura Frader e Sonya Rose -, ou então integrando perspectivas baseadas em gênero em sua estrutura, como, por exemplo, em 
Rethinking Labor History [Repensando a história do trabalho, 1993], de Leonard Berlanstein, que fez um levantamento do campo francês. ${ }^{11}$ Nos anos 1990, o desafio dirigido ao campo por Joan Scott também estava inspirando outras respostas teóricas, baseadas nos primeiros estudos particulares completos, agora representados por Languages of Labor and Gender [Linguagens do trabalho e gênero], de Kathleen Canning. ${ }^{12}$ Em sua Introdução para o leitor de Class, Joyce reconhece a força desses desdobramentos: "O feminismo ofereceu um desafio tão grande quanto se possa imaginar para a soberania da classe na teoria social, sociologia e história. A teoria feminista - e a prática política feminista - ofereceu um novo assunto de análise e novas concepções de identidade para nossa compreensão, na forma do gênero". ${ }^{13}$

Entretanto, apenas seis das 47 leituras que Joyce reúne são escritas por mulheres, e só quatro apresentam uma concepção feminista. Como observamos, a imagem da capa de Class apresenta o oposto de uma trabalhadora, e a qualidade peculiarmente abstrata dessa ilustração específica sugere a dificuldade ainda existente em registrar a diferença que as críticas feministas fizeram para a construção da problemática geral. Às vezes, isso resulta de um atraso incremental, em que a pesquisa empírica corre atrás da consciência já existente no campo. Assim, Lewis Siegelbaum e Ronald Suny abordam explicitamente essas questões da teoria em sua concepção de um volume sobre a formação da classe trabalhadora soviética, entrando na discussão com uma sofisticação teórica agora permitida por historiografias precedentes (da América do Norte, Grã-Bretanha, França, Alemanha e outros países) e insistindo na importância do gênero em particular. Mas a superfície de uma análise baseada em gênero mal e mal é arranhada nas análises práticas das 11 excelentes contribuições desse livro, que exploram aspectos de identidades de classe para uma variedade de circunstâncias da classe trabalhadora entre os anos 1870 e a Segunda Guerra Mundial. ${ }^{14}$ Nesse caso, a consciência teórica estava excedendo a capacidade imediata do campo de cumprir a tarefa. ${ }^{15}$

O Oxford Reader sobre "Classe" não pode usar a mesma desculpa, porque historiadoras como Baron, Canning, Rose, e Scott vêm mudando os termos da discussão - no debate teórico, mas também na prática de pesquisa - por mais de uma década. Isso nos leva de volta à qualidade acentuadamente abstrata das seleções de Joyce, onde a classe reside num repertório de teoria social, e não etnograficamente ou nas literaturas sócio-históricas extraordinariamente ricas sobre esta ou aquela classe trabalhadora específica. Joyce aborda a classe por meio dos clássicos da teoria sociológica (de Karl Marx e Max Weber a Zygmunt Bauman, Alain Touraine, Pierre Bourdieu e Anthony Giddens), por 
intermédio de Jean Baudrillard e Cornelius Castoriadis, da governamentalidade foucaultiana, a 'hermenêutica do social', E. P. Thompson e outros historiadores gerais, e também por meio de debates recentes sobre as 'linguagens de classe'. Dentro desse enquadramento teórico, as feministas, com exceção da própria Joan Scott, de Donna Haraway e Denise Riley, estão em grande parte ausentes. ${ }^{16} \mathrm{O}$ mesmo se aplica a estudos de caso de grupos reais de trabalhadores e trabalhadoras.

Joyce está muito menos interessado em como o gênero muda a análise de classes na base (em todas as histórias sociais particulares que se poderiam descrever ou invocar, como os estudos sobre o paternalismo fabril que o próprio Joyce fez no passado) do que em nos levar para um lugar onde essas histórias sociais de estilo mais antigo não têm mais importância. "Classe" se torna um 'discurso', ou um 'princípio narrativo', uma forma de organizar 'relatos do passado e do presente'. Além disso, esses relatos são enganosos. Para Joyce, classe é uma construção enrijecida de 'origem relativamente recente', que é retroprojetada sobre tempos passados ('imagem lançada de volta sobre o passado') e, com isso, os 'distorce', obscurece as formas de compreensão efetivamente atuantes, como as categorias de 'cidadãos' ou 'povo' (nos estudos de Joyce sobre a Grã-Bretanha do século XIX). É nessas 'concepções de classe' retroativas que os historiadores e historiadoras deveriam estar se concentrando, de acordo com Joyce, chegando ao que está por detrás das linguagens dominantes para encontrar 'novos atores e novas narrativas' para substituir as antigas interpretações baseadas em classes, que foram desacreditadas pela mudança social contemporânea (a 'condição pós-moderna'), a política (fim do comunismo) e o progresso epistemológico (teoria pós-moderna). ${ }^{17}$ Joyce gostaria que teorizássemos os termos da identidade, e não tentássemos complicar a cotidianidade das relações de classe em histórias sociais do local de trabalho, do bairro e da casa. Essa é uma ironia com que as feministas estão familiarizadas. As trabalhadoras finalmente chegam às páginas dos historiadores e historiadoras sociais, e a teorização da classe prontamente migra para outro lugar.

\section{Histórias DE LINGUAGEM, HISTÓRIAS DE CLASSE}

Assim, não há nada no voltar-se para a análise do discurso ou da linguagem em si que garanta a discussão do gênero, a despeito do papel pioneiro desempenhado por Joan Scott ao colocar abordagens pós-estruturalistas e 'desconstrutivas' na pauta do historiador ou da historiadora. A 'história da identidade' (do 'si-mesmo e do social') pós-moderna autodescrita por Joyce 
abandona em grau crescente o terreno da história social usualmente entendida em troca de um tipo particular de ponto de vista foucaultiano a partir do qual se possam ler as dispersões e padronizações do poder e do conhecimento. Em contraposição à sua obra anterior Voices of the People [Vozes do povo, 1991], onde a rica cultura dos pobres trabalhadores de Lancashire forneceu o ancoradouro para uma análise original e desafiadora do discurso popular, Democratic Subjects [Sujeitos/sujeitos democráticos, 1994] se restringe à interpretação de duas biografias individuais. Se anteriormente as pessoas trabalhadoras ('classe' num sentido sociológico coletivo) eram o contexto para um argumento a respeito de identificações populistas que desestabilizou criativamente 'a questão de classe', as narrativas sutis e complexas de Joyce a respeito da identidade política no livro mais recente agora circulam livremente pelo século XIX como um todo, sem ancoradouro nos estudos densamente contextualizados da vida da classe trabalhadora que os historiadores e historiadoras sociais passaram a exigir.

Em outras palavras, na trajetória de Joyce há uma atração clara para o que só pode ser descrito como uma história intelectual readaptada com base em leituras restritas da palavra impressa, em vez do arquivo cultural ramificado ainda subjacente à sua obra anterior, Voices of the People. Essa predileção pela história intelectual tem caracterizado outros defensores da análise linguística, de Stedman Jones a Scott, ou, neste tocante, a William Sewell. ${ }^{18}$ Não queremos ser mal interpretados neste ponto. Não há nada de errado com a história intelectual ou com leituras de fontes publicadas em si. Pelo contrário, sustentaríamos o ímpeto empoderador de obras como Work and Revolution in France [Trabalho e revolução na França], Languages of Class [Linguagens de classe] ou Gender and the Politics of History [Gênero e a política da história] ao longo das últimas duas décadas. Mas tanto para Joyce quanto para Stedman Jones, ao menos, essa agora parece uma opção excludente. A legitimidade da análise social parece ser atualmente disputada como tal, como algo distinto e problemático, tornado inválido por erros epistemológicos, em comparação com histórias que reconheçam a primazia da linguagem. Mas por que a atenção à linguagem deveria exigir o menosprezo da história social dessa maneira?

As mais convincentes objeções ao ensaio de Stedman Jones sobre o cartismo - que originalmente estabeleceu o conflito entre linguagem e história social - não eram contra a importância do estudo da linguagem em si (seja como estratégia de pesquisa ou como programa teórico), mas contra a qualidade atenuada da prática específica de Jones, que passou das propostas radicais da análise linguística para um relato exegético direto da retórica pública dos 
cartistas. À parte da proposta substancial que Stedman Jones faz aqui a respeito da natureza do radicalismo cartista (que continua sendo em grande parte persuasivo), isso substituiu o arquivo da história social (seus locais, contextos e fontes) por uma história intelectual baseada estreitamente em textos publicados, uma mudança que só foi fortalecida nesse meio tempo. Nos mais de 20 anos que se passaram desde que Stedman Jones apresentou seus argumentos pela primeira vez, ele se retirou mais ainda para o interior da história de tradições intelectuais formais (do socialismo utópico, passando pela economia política, até legados do iluminismo), em vez de aprofundar seu argumento sobre o cartismo. ${ }^{19}$ As complexidades da linguagem cartista - seu ordenamento em torno de campos discursivos múltiplos e incomensuráveis, em que a incompletude e as instabilidades de sentido tinham tanta importância quanto as unidades de seu apelo externo - foram ignoradas com excessiva rapidez. Criticando, com razão, o materialismo não problematizado comumente pressuposto por historiadores sociais, Stedman Jones propôs uma concepção supersintetizada de linguagem política pública no lugar dele. Como Robbie Gray observou na época, a linguagem "tem múltiplas camadas, é complexa, fraturada, composta de incoerências e silêncios, bem como do fluxo tranquilo de discursos públicos que se pretendem autoritativos", e deve, por isso, ser lida levando em conta tanto suas exclusões quanto seus apelos unificadores. ${ }^{20}$

Joan Scott ajudou a definir o espaço onde os historiadores e as historiadoras sociais poderiam fazer tais leituras. Trazendo à luz a exegese de Stedman Jones e rompendo os silêncios dela a respeito do gênero, ela deslocou o foco da "política particular" do cartismo para "os processos pelos quais as relações sociais foram concebidas e construídas". Como ela argumenta: "Uma teoria de sentido que pressuponha uma multiplicidade de referências, uma ressonância que vá além de formas de expressão literais, um jogo que abranja vários temas e esferas torna possível apreender como funcionam as conexões e interações". Se se considera que o potencial de contestação ("reinterpretação, reafirmação e negação") está inscrito na produção de sentido como tal, o problema da mudança também pode ser compreendido. ${ }^{21}$ Essa é, em parte, uma questão de fontes. Uma noção ampliada de textualidade se tornou um dos ganhos libertadores da nova história cultural. Mesmo no que se restringe à 'política' (em contraposição à história social), o arquivo em potencial se tornou imensuravelmente mais rico do que antes. James Vernon, por exemplo, ao estudar a política popular do século XIX, evita o terreno normal da história política ("as organizações, o pessoal ou as políticas das instituições nacionais da política”) e procura, em vez disso, os "vestígios negligenciados como baladas, banners, 
charges, folhetos, estátuas, arquitetura, os usos do tempo e do espaço, e o rico veio de formas cerimoniais e iconográficas", bem como releituras criativas de fontes-padrão "como jornais e registros eleitorais" a fim de ampliar nossa compreensão de como a política funcionava ("as formas pelas quais a política definia e imaginava as pessoas"). ${ }^{22}$

Mas o desafio de Scott também enriqueceu a própria história social. Os sentidos culturais se tornaram constitutivos para as relações sociais, a economia e outros aspectos da vida material no trabalho de muitos historiadores e historiadoras recentes, e não há razão pela qual 'o social' deveria ser considerado apreensível como efeito da análise linguística somente, da maneira como Joyce e Stedman Jones agora parecem sugerir. Cada um à sua própria maneira, Michael Sonenscher, Richard Biernacki e Robbie Gray mostraram a necessidade da análise cultural para que os sentidos do trabalho sejam compreendidos. ${ }^{23}$ A guinada linguística certamente não foi o único impulso para a inovação na década de 1980. Os estudos sobre gênero e trabalho já estavam em andamento antes de Scott publicar seus ensaios, assim como estavam as críticas do Estado de bem-estar social baseadas em gênero, e nenhuma dessas duas áreas foi especialmente influenciada pela teoria pós-estruturalista em si. ${ }^{24}$ Mas de todas essas formas as historiadoras feministas que operam com a questão de gênero vêm mostrando o caminho a seguir. Se há uma "percepção aguda da 'crise epistemológica' que tem acompanhado a indagação feminista a respeito de categorias, narrativas e cronologias estabelecidas", então o estudo das classes tem se beneficiado vigorosamente das revisões feministas. ${ }^{25}$ Se Stedman Jones atacou os hábitos de explicar a política de movimentos por sua sociologia (de derivar o cartismo de relações de classes e mudanças sociais na economia) e ajudou a desestabilizar abordagens da classe trabalhadora baseadas em teorias produtivistas ou socioestruturais do trabalho, chances na vida e desigualdade social, coube a outros mostrar como a análise baseada em classes pode se tornar viável de novo.

Ao explorar a importância constitutiva do gênero na política da formação da classe trabalhadora, a obra de Kathleen Canning desprendeu a classe da soberania de interesses econômicos e sociais 'objetivos' (Canning, 1996). Fundamentada em estudos imaginativos e meticulosos de mercados de trabalho, organização do local de trabalho, culturas profissionais, dinâmica de famílias e lares, relações industriais etc., ela, não obstante, abre a formação da classe para um processo mais amplo de definição cultural e política. Aqui, ao menos, a história social do tipo clássico e leituras da linguagem e da história política são tudo menos incompatíveis. Os sentidos do conceito de classe se tornam 
historicizados por meio do tipo de análise discursiva que Scott havia proposto. $\mathrm{Na}$ obra de Canning, a classe trabalhadora alemã pré-1914 aparece como uma formação parcial, historicamente situada e contingente cujas instituições e subculturas e suas solidariedades e divisões ofereciam formas vigorosas mas excludentes de organização do universo social - e algumas das mais cruciais delas estavam estruturadas em torno do gênero. Mas, por mais vigorosas que tenham sido a lógica do local de trabalho e outras experiências (os processos locais e cotidianos da vida da classe trabalhadora), elas só poderiam ser moldadas, sempre, por forças mais amplas, que às vezes vinham de fora (Estado, igrejas, partidos, agências caritativas, bens comerciais) e às vezes atuavam nas próprias comunidades da classe trabalhadora e por meio delas, e as linguagens de todas precisam ser deslindadas e entendidas. Além disso, por mais exatamente que as linguagens da identidade da classe trabalhadora fossem ordenadas, elas continuavam sendo apenas uma de "diversas formas possíveis de descrever, ordenar, organizar e compreender as realidades muitas vezes diversificadas e contraditórias das vidas e experiências diárias dos trabalhadores" sob o capitalismo. A formação da classe trabalhadora era um conjunto nunca concluído e instável de histórias possíveis nesse sentido. Como disse David Crew:

Na Alemanha, entre 1890 e 1933, as linguagens de classe tinham de competir com muitas outras linguagens sociais e políticas - catolicismo, nacionalismo, liberalismo, nazismo - que ordenavam os mesmos fatos sociais de formas bem diferentes e lhes davam outros sentidos e importância. (Crew, 1997, p.50)

\section{O 'POLÍTICO’ E O 'SOCIAL'}

Quando publicamos nosso artigo anterior em 1980, "Why Does Social History Ignore Politics?" [Por que a história social ignora a política?], era esse campo complexo de interconexões entre as histórias sociais do trabalho e as práticas organizadas da política que estávamos tentando abordar (Eley; Nield, 1980). Daquele ponto de vista anterior, eram justamente as compreensões enriquecidas da história social, em conjunção com redefinições contemporâneas da categoria do político, que incitaram nossa crítica - não porque nos opuséssemos a qualquer uma dessas coisas (muito pelo contrário), mas porque estávamos preocupados com a lógica de sua fusão. Para explicar a direção de nosso argumento atual - explorar como as exposições do conceito de classe e as exposições da política poderiam estar atuando juntas agora -, faz sentido retomar até certo ponto essa história intelectual-política anterior. ${ }^{26}$ 
Em sua fase heroica (digamos, de meados dos anos 1960 a meados da década de 1970), os historiadores e historiadoras sociais se definiam contra a estreiteza da história política assim como ela era praticada e entendida então. Mas à medida que o tumulto político da época também invadia as salas dos seminários, o argumento positivo em favor da história social se tornou não só o poder das determinações sociais na explicação de como a política tinha lugar no topo, embora isso fosse fundamental. Ele era também um argumento pela expansão dos sentidos da política na sociedade em geral. Um efeito decisivo do impulso da história social foi uma expansão radical da política - isto é, uma percepção ampliada do 'político' nas partes ordinárias da vida social. Locais anteriormente 'não políticos' (o local de trabalho, o bairro, a subcultura, a família, o lar) foram reclamados para a 'política' de maneira nova, às vezes pela primeira vez. Esses lugares já estavam presentes como objetos de política pública, por meio do direito, da assistência social, da administração social. Mas agora eles foram reclamados como locais de identificação e contestação política também, como lugares onde o poder era organizado e corporificado. Esse deslocamento de perspectiva fez a política passar das arenas institucionais convencionais (o Estado, os partidos e as organizações públicas em sentido mais estreito) para um âmbito muito mais amplo e menos gerenciável da sociedade. Levou a política 'para fora de casa'. Permitiu que as maiores questões da vida política - os potenciais de estabilidade e coesão na ordem social, as possiblidades de conformidade e oposição e as circunstâncias sob as quais interesses e valores dominantes poderiam ser contestados, restaurados ou até superados - fossem colocadas de modo muito diferente. 'O pessoal é político' foi uma designação drástica dada a essa abertura, e o radicalismo da época encontrou cada vez mais locais políticos num terreno potencialmente ilimitado de transações cotidianas anteriormente privadas e não reclamadas.

Nesse período, a história social produziu duas lógicas distintas e compensatórias. Se, num sentido, a guinada para a história social incentivou uma definição da 'sociedade' como uma grandeza separada e distinta da política, em outro sentido ela descobriu potenciais políticos justamente dentro do próprio 'social'. Se uma consequência possível foi a despolitização do social e sua transformação num objeto separado e gerenciável para o estudo, outra foi justamente investi-lo de sentidos políticos. A tensão dessas duas lógicas gerou tanto empolgação quanto frustração, tanto a identidade compartilhada quanto a cizânia na história social. Quando alguns historiadores e historiadoras sociais defenderam que se voltasse a conectar explicitamente o trabalho sócio-histórico com a esfera política, na segunda metade dos anos 1970, numa época de 
debate teórico sobre a especificidade do político e suas autonomias, a divisão aumentou. Ao longo da década de 1980, por combinações de novos campos empíricos, política radical e teorização ampla, muitos historiadores e historiadoras sociais chegaram a uma compreensão do que a política inclui. Essa nova compreensão diferia de modo marcante dos pressupostos com os quais eles e elas tinham iniciado originalmente, quando a história social fora vista como uma alternativa contextualmente determinante e conceitualmente superior a um modelo estreitamente institucional da vida política. Nessa nova situação, voltar à política - isto é, tentar reconceitualizar a relação entre 'o social' e 'o político', depois de as fronteiras mais antigas e limitantes terem sido rompidas - parecia uma tarefa cada vez mais urgente. Mas voltar a juntar a 'sociedade' e a 'política' tem sido uma coisa imensamente complicada.

Simplificando enormemente, tem havido dois caminhos principais. Um deles veio por intermédio da teoria do Estado. A compreensão ampliada de política que acabamos de descrever trouxe uma apreciação expandida mas desinstitucionalizada do envolvimento do Estado na sociedade, ultrapassando os limites do governo em sentido mais estreito para incluir áreas da administração social, saúde pública, lei, escolarização, prática e crença religiosa, organização da vida privada em famílias, sexualidade, divisões de gênero, trabalho assalariado e em casa e as distinções cambiantes entre o privado e o público. Em todas essas dimensões, especialmente sob o impacto do feminismo, o poder público foi rastreado por todas as principais vias e passagens até os espaços protegidos e cantos ocultos da vida social. Agora a presença do Estado é procurada de formas menos visíveis e mais indiretas do que antes. Percebe-se que, para além da atividade convencional do governar, o Estado consiste em sistemas mais amplos de regulamentação e intervenção, implicando o processo maior de reprodução social, de construção e reconstrução de relações sociais nas mais amplas frentes. Em seus primórdios, a história social muitas vezes implicava uma distinção mecânica entre 'sociedade', de um lado, e 'Estado', 'ideologia' e 'política', de outro. Mas assim, longe de se situar num dos lados dessa dicotomia, a história social se posicionou em grau crescente dentro do complexo campo de forças entre os dois. ${ }^{27}$

O segundo caminho tem sido mediante várias espécies do que poderíamos chamar de 'culturalismo', se um momento anterior de polêmica não tornasse isso pouco recomendável. ${ }^{28}$ Entre a grande quantidade de influências importantes aqui, que vão de Thompson e Clifford Geertz, passando por Bourdieu, os estudos culturais, o feminismo e a teoria literária até vários pós-estruturalismos, queremos selecionar a recepção de Michel Foucault, pois Foucault 
ajudou a mudar nossas percepções da política mais ainda, confirmando o afastamento das instituições principais do Estado no sentido nacional-centralizado rumo à sua 'microfísica', ao que ele chama de surgimento de novas estratégias individualizantes, que funcionam "fora, debaixo e ao lado dos aparelhos do Estado, num nível muito mais diminuto e cotidiano" (Foucault, 1980, p.60). $O$ poder, nesse sentido, torna-se mais ampla e insidiosamente difundido por toda a sociedade do que as antigas antinomias entre história social e política, ou entre a sociedade e o Estado, nos permitiam conceber. O poder - e, portanto, o sentido político - está organizado em todos os tipos de instituições sociais, práticas culturais e transações informais, bem como nos contextos formais da política nacional e local, e nos locais mais visíveis e óbvios de tomada pública de decisões. O poder - e, assim, as oportunidades de ação política - está estruturado nos mais básicos e geralmente não mencionados pressupostos por meio dos quais percebemos nossa relação com o mundo social e as práticas do cotidiano. Consequentemente, o poder não é mais apenas propriedade do Estado - quer vejamos isso como coerção e intervenções repressivas, ou como uma maquinaria de aparelhos ideológicos, quer, mais amplamente, como o conjunto de instituições públicas -, mas também pode ser procurado nas menores e mais íntimas relações humanas.

Se o 'poder', ou ao menos nossa compreensão de como ele está ordenado e de onde se encontra, tem "se movido por todo o espaço social", então a 'cultura' (como a produção, intepretação e contestação de sentido) se torna vital para a maneira como sua definição precisa ser abordada (Dirks; Eley; Ortner, 1994, p.5). Isso exigiu certo obscurecimento de categorias e um reconhecimento de sua permeabilidade mútua - um reconhecimento antirreducionista de que a política, o direito, a cultura e as crenças não são externos à economia e suas relações sociais ou uns aos outros, mas sempre já estão imbricados juntos em unidades complexas de estrutura e ação, indissolúvel e constitutivamente interconectadas em práticas concretas, acontecimentos específicos e vidas individuais. Tal reconhecimento incentiva um interesse na micro-história, nas histórias ocultas do cotidiano, porque é aqui que a dinâmica dessas relações e sua interconexão profana poderiam ser abordadas de modo realista. Além disso, se o poder se encontra em arranjos sociais e formalmente políticos, e a cultura pode ser tanto um efeito quanto um meio de dominação, então todas as relações mundanas do cotidiano ficam debaixo da influência do poder. As pessoas em suas identidades multiformes, pensando e agindo em todas as diferentes dimensões de suas vidas, todas produzem e são produzidas por relações de poder - isto é, relações em que os participantes estão continuamente 
negociando e renegociando aspectos de desigualdade, a autoridade e a capacidade de definir os sentidos do mundo.

Aqui é o elemento da negociação que é chave. Se o poder assegura o silenciamento de certas vozes ao ordenar o mundo vivenciado dentro de regimes definidos de verdade, permitindo que algumas coisas sejam faladas de maneira fácil ou legítima, ao passo que outras coisas normalmente ficam não ditas, nós certamente não podemos aceitar isso. Pois, assim, o poder também coloca a si mesmo em risco, ao produzir posições a partir das quais sujeitos podem tentar falar. Essa é uma advertência absolutamente vital, frequentemente negligenciada quando o 'poder' e a 'dominação' estão em discussão: as relações de poder nunca são simplesmente vetores de dominação ou 'controle social', mas são simultaneamente meios de possível contestação, e às vezes até de emancipação também. Como repetia Foucault, onde há poder, sempre há resistência. Se esse aspecto deve ser compreendido, se as tentações politicamente incapacitantes de uma concepção excessivamente totalizada de poder como dominação podem ser superadas, então é preciso pensar tanto a 'resistência' quanto o 'poder'. Com efeito, talvez Antonio Gramsci deva ser acrescentado a Foucault.

É aqui que nosso artigo anterior tentou intervir. Sustentamos que a concepção gramsciana de hegemonia, com sua ênfase no consentimento em contraposição à dominação e nos processos de persuasão moral necessários para que a aquiescência ou participação popular num ordenamento particular do mundo possa ser assegurada, é um excelente lugar para começar. Ela aceita o caráter difuso do poder na sociedade e certamente pressupõe a inscrição de sentidos políticos tanto nas relações sociais quanto nas práticas do cotidiano das formas às quais já se aludiu. Mas também conceitualiza o poder como um espaço de contestação e terreno de luta, e não como uma via de mão única. Contudo, enquanto historiciza o poder e salienta as contingências e conjunturas das quais os regimes de poder dependem, a hegemonia também postula as desigualdades estruturadas que predispõem certos conjuntos de resultados em contraposição a outros, as cartas marcadas da propriedade, do acesso e do controle concentrados, o que assegura que qualquer processo sustentado e eficaz de contestação será uma luta extenuantemente dificultosa, que exige mais do que simplesmente recursos individualizados e locais para funcionar.

Em outras palavras, Gramsci nos lembra (ou permite não esquecermos) que, além de estar insidiosamente disperso, o poder também está organizado, acumulado, monopolizado, armazenado, guardado para quando for preciso, configurado dentro de instituições, concentrado dentro de formas de agência, normalizado e sistematizado dentro de uma esfera pública, naturalizado e 
tornado opaco. É claro que essas modalidades de grande escala ou societais não são menos suscetíveis à contestação. Mas há um sentido, por exemplo, em que uma ênfase pós-foucaultiana na dispersão do poder pode nos afastar desnecessariamente do poder na forma centralizada no Estado, de modo que quando o poder nesse sentido mais convencional fala - por meio de exércitos, decretos emergenciais, policiamento e repressão -, somos deixados a protestar de maneira ineficaz a partir da margem. Enfocar a microfísica do poder também pode obscurecer as regularidades e normatividades, a lógica da estruturação social, para cuja revelação o conceito de classe é necessário. Isso talvez devesse ser óbvio. Dizer que o poder não tem um único centro não significa que locais centralizados não possam ser encontrados, ou que de alguma forma tenhamos permissão para ignorar o Estado, ou que diferenças de classe não tenham potencial generalizável para a ordem da sociedade toda. A ideia gramsciana de hegemonia nos dá uma maneira de perceber justamente como fontes e locais diferentes de poder podem ser organizados para atuar em conjunto.

Finalmente, se Foucault e Gramsci são complementares para repensar a relação entre política e sociedade - um fazendo do poder uma dimensão de todas as relações sociais, o outro retornando à especificidade da política como processos de construção hegemônica -, há uma terceira influência-chave, a saber, três décadas de teoria feminista. Por um lado, a crítica feminista tem sido essencial para expandir o político das formas que vimos sugerindo - isto é, afastando-se da política no antigo sentido institucional e centrado no Estado e aproximando-se dos outros locais e situações onde ocorre a contestação. Família, saúde, sexualidade, alimentos, reprodução, o corpo em geral - todos esses elementos entraram no discurso político de formas novas graças ao feminismo, tendo efeitos profundos sobre a maneira como os historiadores e as historiadoras sociais passaram a abordar seu trabalho. Por outro lado, tais críticas problematizaram suposições mais antigas a respeito do indivíduo como sujeito que age racionalmente, seja como autor de iniciativas políticas ou como seu objeto visado. A percepção pós-estruturalista de que o próprio poder produz formas de subjetividade, e não opera sobre indivíduos autônomos já constituídos, foi retomada extensivamente por feministas, produzindo efeitos desestabilizadores para a maneira como questões de agência, experiência e consciência podem ser abordadas agora. A teorização do gênero como construção móvel da diferença sexual, o reconhecimento de que pressupostos de masculinidade e feminilidade determinados pelo gênero estão inscritos nas linguagens básicas da identidade social e a afirmação radical de que tudo é determinado pelo gênero (nada é livre 
de codificações e assimetrias de gênero) são, agora, dimensões inescapáveis da exposição que estamos procurando oferecer.

\section{De volta Ao Conceito de Classe}

Em nosso ensaio anterior expressamos a preocupação de que o foco na história social, particularmente em suas versões 'culturalistas', estava incentivando os historiadores e as historiadoras do trabalho a subsumir as especificidades da história política em argumentos excessivamente generalizados sobre a 'hegemonia' e o 'controle social'. Isto é, o termo gramsciano era usado de tal maneira que entendia todo o processo de negociação que acabamos de descrever como algo dado, como uma fronteira muito impermeável, atrás da qual se podiam escrever histórias sociais, e onde as culturas populares e experiências da classe trabalhadora podiam revelar suas formas de resistência. Usando o exemplo do Partido Social-Democrático alemão (SPD), sustentamos que as histórias institucionais do trabalho (partidos e sindicatos) eram um local-chave para a produção do consentimento da classe trabalhadora, ou seja, como os contextos onde a lógica e os potenciais de conformidade, oposição, aquiescência, independência, assimilação, resistência, indiferença, raiva, gratidão, deferência e franca recusa podiam ser traduzidos do caráter cotidiano da experiência da classe trabalhadora para uma agência política aproveitável para fins locais e nacionais. Isso não era qualquer espécie de rejeição da história social de nossa parte, mas um apelo em favor de novas formas de manter juntas a história social e a política. De fato, vimos algumas das novas tendências, como a Alltagsgeschichte (história do cotidiano) na Alemanha, como muito úteis, tornando mais fácil evitar armadilhas anteriores. ${ }^{29}$ Sustentamos que, ao tentar entender as capacidades para a conformidade e a oposição na classe trabalhadora alemã antes de 1914, a história do SPD não deveria ser esvaziada. Pelo contrário, em vez de duvidar da relevância desse partido para a experiência ordinária da classe trabalhadora (um tropo-padrão de discussão, especialmente no que diz respeito ao marxismo do partido), deveríamos estar explorando as formas complexas pelas quais ela estava e não estava inserida.

Em outras palavras, estávamos tentando criar um espaço para a análise política no sentido ampliado dado a 'política' pela política de conhecimento de 1968. Estávamos preocupados com a redução da política à cultura por meio de versões simplificadas de Gramsci, onde 'hegemonia' exercia a função de um nome para designar o fechamento da contestação cultural num sentido societal totalizado. Isto é, a estabilidade do capitalismo e de suas relações de dominação 
estava sendo conceitualizada com excessiva facilidade por meio de um modelo abstrato e excessivamente generalizado de consenso da sociedade toda, de uma cultura dominante oniabrangente, para o qual os vocabulários 'gramscianos' de hegemonia ameaçavam tornar-se uma chave-mestra. Em sua concretude, $\mathrm{e}$ nesse meio-tempo, as histórias sociais da classe trabalhadora que se acumulavam (abrangendo várias historiografias nacionais) constituíram um acréscimo imenso ao nosso conhecimento, e uma variedade de réplicas excelentes à nossa queixa de 1980 poderiam ser citadas agora. ${ }^{30}$ Mas sugeriríamos que o universo institucional da política - em que os aparelhos de Estado, agências civis, partidos e todo tipo de organizações têm sua parte - ainda permanece relativamente negligenciado.

Qual é a resposta? Ira Katznelson insiste em que os historiadores e historiadoras sociais retornem para a história política, isto é, para o estudo institucional do governo, dos partidos e do direito. Invocando nosso próprio artigo, ele sustenta que "a fratura que divide a história social da política não só tornou impossíveis as análises do âmbito entre o Estado e a sociedade civil, mas prejudicou nossa compreensão da constituição mútua das instituições e da cultura, da organização e da ideologia" (Katznelson, 1994).

Até aqui, tudo bem. Mas em meio à inteligência geral da exposição de Katznelson, temos algumas discordâncias básicas. Endossamos seu desejo de evitar binarismos de uma opção baseada na epistemologia (entre "versões marxizantes, desde hard até soft, de causalidade linear que flui da base material para construtos superestruturais secundários, e, também, a eliminação completa do dualismo de estrutura e agência"), e gostamos da ideia de manter as duas numa tensão criativa, para ver como a "plasticidade da identidade" e as formas institucionais da política combinam umas com as outras (ibidem, p.9). Mas ao tornar o institucional categoricamente separável como objeto de pesquisa, corrigindo sua negligência por parte de estudos independentes do âmbito institucional, ele cria uma nova separação. Além disso, suas recomendações positivas confirmam nosso ceticismo, pois nem as obras de Henry Pelling nem a coletânea editada por Eugenio Biagini e Alastair Reid fundamentam suas histórias políticas nas densidades da história social que temos em mente. ${ }^{31}$

Como diz Katznelson, a obra de Pelling reflete "a busca para entender como o movimento trabalhista na Grã-Bretanha, em todos os seus aspectos, forjou vínculos institucionais de representação, influência e negociação com o Estado dentro de um marco amplamente liberal de direitos e cidadania". ${ }^{32}$ Mas a obra de Pelling tem pouca relação com a vasta historiografia da formação da classe trabalhadora gerada durante as últimas poucas décadas na 
Grã-Bretanha, com seu mapeamento intensivo de culturas profissionais e ocupacionais, geografia industrial e estudos de comunidades. ${ }^{33}$ Mais precisamente, ela não faz nenhum esforço para relacionar a ascensão do Partido Trabalhista com as histórias acidentadas da formação de classes nem com as construções instáveis e flutuantes da identidade social, muito menos as inter-relações dinâmicas das duas. É inteiramente isenta de qualquer coisa semelhante à análise de gênero, e isso, por si só, tendo em vista a centralidade das relações de gênero para nossa compreensão dos "vínculos de representação, influência e negociação com o Estado" que Katznelson descreve, compromete decisivamente o corpus de Pelling como modelo.

De modo semelhante, o volume de Biagini e Reid reúne um excelente conjunto de trabalhos sobre a arquitetura da política parlamentar pós-cartista, fundamentando suas afirmações sobre a cultura pública liberal numa série de estudos de caso, alguns dos quais se aprofundam em questões, trajetórias e localidades particulares para suas análises do discurso político popular. Mas essa obra também é uma polêmica contra a história social do tipo estabelecido, insistindo em que a linguagem pública proporciona a melhor chave para as lealdades e o comportamento políticos da classe trabalhadora, em contraposição aos tipos de fundamentação materialista destes últimos que os historiadores e historiadoras sociais têm preferido. "As ideias são importantes", afirma Biagini, "porque o comportamento das pessoas é profundamente influenciado pelo que elas pensam, e especialmente por aquilo em que acreditam firmemente". Consequentemente, a força de ligação crucial de movimentos políticos (no caso de Biagini, o liberalismo gladstoniano) eram "os valores compartilhados por militantes, eleitores e apoiadores em geral”, e não "os interesses materiais dos grupos sociais aos quais eles pertenciam": "Naquela época, a política não tinha a função de proporcionar mudanças legislativas favoráveis para grupos com consciência de classe; ela fornecia, antes, uma identidade coletiva a grupos cujos interesses sociais e materiais não levavam, por si mesmos, a uma consciência de classe politicamente relevante" (Biagini, 1992, p.2).

Ao desvincular a questão política das causalidades deterministas da explicação social, essa afirmação repete o posicionamento antirreducionista básico das duas últimas duas décadas, cujas origens (no caso da Grã-Bretanha) remontam aos primeiros debates 'pós-marxistas' associados a Ernesto Laclau e Chantall Mouffe, e depois aos ensaios de Stedman Jones. ${ }^{34}$ Esse compromisso básico é um que nós também compartilhamos, mas algumas distinções ainda precisam ser feitas. Em primeiro lugar, a abordagem de Biagini e Reid formula um argumento a respeito da existência de amplas continuidades do 
radicalismo britânico desde o início do século XIX até o Partido Trabalhista do século XX, o que permanece enormemente contencioso e problemático. Em segundo lugar, ela pressupõe uma leitura geral da política vitoriana "como política baseada em status e cultura, e não em classe", o que fica sem explicação, enquanto os 'fatos' estruturais de classe e status na moldagem da vida social (em comunidades residenciais, na produção, no acesso a bens sociais, na distribuição geral das desigualdades sociais etc.) meramente servem de sombra para a análise, não entrando nos termos em que ela é feita. ${ }^{35} \mathrm{Em}$ terceiro lugar, toda uma historiografia - rotulada de marxista, mas que subsume tanto as diversidades desta última quanto outras histórias sociais de tipo não marxista - é tachada de 'reducionista' num posicionamento polêmico que inevitavelmente impede o debate. Em quarto lugar, não está claro de modo algum por que defender as autonomias da história política - neste caso, em relação à linguagem política pública - deveria exigir a exclusão total da análise social, e até (nas versões mais extremas) a proscrição completa da explicação social. ${ }^{36}$

Nós queremos romper com essa lógica de repúdio. Pensar de maneira não redutiva - desde o questionamento da soberania do social e do reconhecimento do "caráter discursivo de todas as práticas" até a percepção da autonomia da política - não exige que se abandone a tentativa de fazer história social das formas ambiciosas que nos foram dadas desde a década de $1960 .{ }^{37}$ De modo semelhante, se "reconhecemos que a política ocorre inteiramente dentro do discurso" e "nos recusamos a contrapor o discurso a uma realidade extradiscursiva”, como um axioma da compreensão, com todos os efeitos metodológicos concomitantes, isso não exige que nos abstenhamos da história social nos usos aceitos desse termo (praticada, por exemplo, na obra de Anna Clark, Lizabeth Cohen, Robin Kelly, Stephen Kotkin ou Kathleen Canning), embora os advogados de uma abordagem discursiva às vezes pareçam estar dizendo que deveríamos fazer isso (Stedman Jones, 1997, p.205). Além disso, queremos defender o valor do trabalho que ainda está sendo produzido por historiadores e historiadoras sociais, alguns dos quais citamos, que oferecem abordagens bem mais sofisticadas para a análise da política do que críticos como Joyce, Stedman Jones e Biagini e Reid estão dispostos a sugerir. Como diz Gray: "O melhor trabalho sobre o conceito de classe tem sido determinado por uma percepção aguda das relações complexas, às vezes tensas, entre situações de classe diversificadas e desiguais, e a construção frágil e contingente de interesses e identidades de classe mais amplos" (Gray, 1994). 
Neste ensaio, estamos tentando escapar da polêmica que vem interrompendo e desfigurando a conversa entre historiadores e historiadoras interessados na classe trabalhadora durante as duas últimas décadas. ${ }^{38}$ Ficamos empolgados com a abertura de novas perspectivas teóricas, particularmente aquelas que complicavam as compreensões mais antigas - que permaneceram estáveis e empedernidamente resistentes à crítica durante muitos anos - da relação entre 'o social' e 'o político', de todas as formas às quais já fizemos referência. Fomos inspirados pela guinada linguística por meio da qual os múltiplos antirreducionismos de marxistas, feministas e pioneiros dos estudos culturais nos anos 1970 ficaram tão vigorosamente radicalizados. Somos questionados pela condição da pós-modernidade e aceitamos muitos dos argumentos sobre as transformações contemporâneas do capitalismo articuladas em torno da globalização, do transnacionalismo e da transição pós-fordista. Aceitamos que a reconfiguração de identidades e as condições cambiantes de filiação política, que separam os cidadãos de locais sociais acostumados e anteriormente seguros, são o ponto de partida inescapável para pensar sobre a política no final do século XX - particularmente nas tradições da esquerda, com sua ênfase na agência coletiva de movimentos sociais, a busca conjunta de medidas socialmente organizadas de democracia, as lutas por distribuições mais equitativas do produto social e a imaginação prática de modalidades de mudança na sociedade como um todo. Em meio a tudo isso, acolhemos a crítica da explicação social e a necessidade de todos os debates mobilizados por Joyce e Stedman Jones, que tornaram tão problemática a soberania do social.

Sem levantar pretensões exageradas em favor da influência do marxismo como tal, sustentaríamos que alguns pressupostos materialistas clássicos (às vezes marxistas em termos de derivação, o mais das vezes não) foram o principal fundamento para as novas histórias sociais dos anos 1960 e 1970. Eles incluíam concepções robustas de causalidade social, determinação social e totalidade social; a prioridade analítica do contexto social para que as formas de política e ideologia numa sociedade sejam entendidas; e a valência fundamental da explicação social para ideias de estabilidade e mudança histórica. Nessa história intelectual, 'classe' tendia a servir de categoria principal geralmente aceita. Seu vigor para a história do trabalho era sua utilidade totalizadora. Ela não fornecia só um meio eficaz de organizar a análise do universo social; também continha uma inscrição de sentido e agência políticos. Fornecia um instrumento de análise extraordinariamente flexível nesse tocante. 
Quando a história do trabalho ampliou sua responsabilidade após a década de 1960, ela incentivou três tipos de envolvimento com a política. Explorou processos institucionais e suas formas conjunturais, e por fim estendeu isso dos partidos e do Estado para as formas de poder que atuam pelas costas das pessoas, de formas não acessíveis a estudos de experiência, agência ou consciência numa modalidade thompsoniana. ${ }^{39}$ Incentivou a ligação do trabalho histórico com um projeto mais amplo de fazer do mundo um lugar melhor - por exemplo, recuperando incidentes e momentos de lutas de classes que enfatizavam continuidades do passado com o presente, fazendo de histórias sociais e culturais uma ponte para transformações contemporâneas. E inspirou a revelação de narrativas 'ocultas da história', como meio de enriquecer a análise histórica e de fornecer relatos autoconscientemente gerativos destinados (como nas primeiras ondas da história das mulheres) a inspirar uma política justamente atacando as narrativas excludentes da historiografia convencional. Mas se consideramos cada uma dessas três formas da relação da história do trabalho com a política de um ponto de vista dos anos 1990 - os âmbitos institucionais da política e da esfera pública, a melhoria do mundo contemporâneo, a produção de contranarrativas dentro da valorização de identidades subalternas -, fica prontamente óbvio que as metanarrativas estruturais e incrementais de classe não podem mais cumprir a mesma tarefa.

Entre historiadores e historiadoras, a crença mais antiga de que a melhor maneira de explicar as ações das pessoas é por sua localização social, suas identidades sociológicas e seu enquadramento em categorias sociais 'objetivas' como classe, entendidas em termos socioestruturais ou em outros termos materialistas, sofreu um dano considerável. De igual maneira, a contra-afirmação dessa crítica antimaterialista, de que as categorias básicas da compreensão social moderna não são as 'realidades objetivas' tão frequentemente supostas, mas são, ao invés disso, construídas historicamente, também é agora objeto de ampla concordância. A partir de nossa crise contemporânea do conceito de classe, podemos apreciar melhor as dificuldades de fazer da classe uma categoria trans-histórica de análise para sociedades capitalistas industriais em geral, cuja lógica de desenvolvimento tinha direção clara, com efeitos na política e na cultura entendidos transparentemente. Agora podemos perceber mais claramente as especificidades da história que sustentam a tradição política socialista como uma espécie de agência política de classe com pretensões mais amplas de liderança nacional. Essas histórias implicavam uma constelação de ambientes urbano-industriais e estruturas sociais a eles associadas, muitas vezes demarcada em termos geográficos, residenciais e visíveis contra o resto da 
sociedade, apoiando culturas da classe trabalhadora separadas, e moldada por relações claras com o governo local e central. Na Europa ocidental, a formação de universos proletários distintos entre os anos 1880 e 1920 cristalizou solidariedades culturais e organizacionais que foram exitosamente articuladas em partidos comunistas e socialistas entre as guerras, tendo efetividades políticas que duraram até a década de 1960 e depois dela.

Se historicizamos a política de classe desse modo - considerando a política de classe como um repertório distintivo e historicamente localizado de linguagens para organizar o universo social, alcançando seu ponto de apoio dos anos 1880 até 1960, com uma relação variável e contestada com as histórias sociais anteriormente consideradas determinantes -, chegamos muito mais longe com a questão da discursividade. Esta última está sendo oferecida por polemistas de cada um dos lados como uma opção polar entre opostos 'discursivos' e 'realistas', onde um é ou sofisticado e epistemologicamente puro ou então irremediavelmente teoricista e afastado das sociedades reais, e o outro é ou fundamentado ou bem atestado ou então irremediavelmente atolado no conservadorismo. Aqui, no interesse do diálogo e da colaboração, proporíamos uma pragmática da boa-fé. Por um lado, os defensores do conceito de classe poderiam reconhecer - ainda que apenas estrategicamente, e durante certo tempo - as dificuldades espinhosas, em termos metodológicos e teóricos, de analisar a política da classe trabalhadora como resultado indicativo de um interesse de classe e de uma posição socioestrutural economicamente localizados. Por outro lado, os advogados do 'pós-modernismo' ou da 'história discursiva' poderiam reafirmar a utilidade de que os historiadores e historiadoras sociais continuem a fazer seu trabalho, mesmo que seja só para gerar estudos cuidadosamente construídos e baseados em arquivos que eles, depois, possam 'ler'. Essa pausa para respirar, ou suspensão mútua da descrença, poderia reduzir a velocidade com que números crescentes de (ex-)historiadores sociais estão tratando a história social como um conjunto de práticas ultrapassadas que merecem ser repudiadas, pois na atual polêmica há o perigo de desconectar a rica e detalhada história social de classe das próprias explicações de mudanças políticas que ela se destinava a subscrever.

Tendo em vista o enigma básico de atribuir unidade intersubjetiva a uma categoria social, especialmente uma categoria tão dividida por diferenças internas, é útil ver a formação de classes mais como um postulado cultural e político (afirmando um modelo particular de identidade social) do que como um fato social demonstrável (a criação de novas posições sociais definidas por relação com os meios de produção ou algum outro critério material). 
Sustentaríamos que a classe entendida discursivamente é um ponto de partida melhor para o estudo da formação de classes do que as abordagens clássicas da ciência econômica e da estrutura social, porque foi nesse nível discursivo que uma nova coletividade operacional (a classe em suas formas efetivamente existentes) foi definida - quem chegou a ser incluído, quem formou as fronteiras, quem deu o tom e quem conquistou a voz reconhecida.

Sejamos claros: este é um ponto de partida conceitual, não uma decisão em favor de certos tipos (ou fontes) de história e contra outros. Ele não significa que a ciência econômica (composição do capital, regimes de acumulação, mercados de trabalho, divisões de trabalho, tecnologias de aptidão, relações no local de trabalho, sistemas de salários e aprendizados) e a história social (bairros e comunidades, famílias e lares, sexualidades, recreação e tudo o mais) não devam ser estudadas. Mas as linguagens de classe estavam inextricavelmente inseridas em todas essas coisas - em práticas e culturas do cotidiano, bem como nas codificações e afirmações oficiais de organizações, da literatura e da imprensa, e todos os outros tipos de discurso público. O discurso de classe, uma insistência na classe como a realidade organizadora das sociedades capitalistas emergentes, além do crescimento de práticas e organizações específicas em torno dessa insistência (como sindicatos e partidos socialistas), moldaram constitutivamente essas histórias sociais desde o início. Em outras palavras, a história de classe é inseparável da história da categoria. A classe emergiu historicamente como um conjunto de afirmações discursivas sobre o universo social que tentava reordenar este último em termos de si mesmo.

Essa passagem discursiva - da pressuposição de uma realidade objetiva de classe ao estudo de como a categoria de 'classe' veio a ser feita, por meio de todos os programas e métodos da história social, bem como das novas explicações culturais e intelectuais - pode ser extraordinariamente frutífera. Ela livra a análise da teleologia de uma consciência de classe que se pensa estar inscrita na lógica direcional baseada em interesses da experiência coletiva de classe. Também nos livra da necessidade de álibis - da busca de explicações especiais quando as versões idealizadas da consciência de classe não surgem. Em vez de ver os interesses da classe trabalhadora como uma base para ação estruturalmente dada e acordada, poderíamos tratar a própria ideia de 'interesses' como um problema, o efeito discursivo de histórias complexas que precisam primeiro ser exploradas. Em vez de perguntar que interesses da classe trabalhadora foram refletidos em que organizações e formas de ação (um projeto clássico da história do trabalho), poderíamos examinar como práticas e instituições particulares incentivaram ou obstaculizaram construções definidas do 
interesse da classe trabalhadora. A transmissão entre interesse e ação é de mão dupla. Como campo discursivo, os interesses da classe trabalhadora não são redutíveis a qualquer contradição essencial única do capital e do trabalho. Assim, longe de essa contradição ser estruturalmente constitutiva para a ascensão do movimento trabalhista em alguma forma necessária e direta, os movimentos trabalhistas foram efetivamente moldados a partir do campo de força entre as condições emergentes e sua tradução discursiva cada vez mais intensa.

Isso nos leva de volta às pluralidades da linguagem - às muitas forças diferentes que atuam sobre as vidas das pessoas trabalhadoras e por meio delas, à fala ininteligível da interpelação, que lhes permite se reconhecer de diversas maneiras possíveis. Essas qualidades indeterminadas da identidade da classe trabalhadora, sua não fixidez, lembram-nos dos silêncios e exclusões que os apelos à classe sempre implicam. A maneira como nos vemos como base para a ação, a maneira como somos abordados como tipos particulares de públicos não são fixas. Nós nos reconhecemos de formas variadas - como cidadãos, trabalhadores, consumidores, pais, seres sexuais, entusiastas de esportes e hobbies, públicos para música e cinema, pessoas que acreditam em credos religiosos e outros, gerações, objetos de políticas públicas e vigilância, sujeitos de raça e nação etc. Tais reconhecimentos são estruturados por relações de poder de várias espécies. Eles são determinados pelo gênero, por meio de pressupostos que nos situam como homens ou mulheres. Num certo nível, essa observação não é especialmente controvertida. A qualidade fragmentária, complexa, não fixa de posições de identidade ou sujeito não só é um lugar-comum no discurso contemporâneo sobre a identidade, mas também tem autorização em tradições mais antigas da teoria social. Mas a política geralmente é conduzida como se a identidade fosse fixa. A questão, então, torna-se a seguinte: como a identidade se estabelece e congela? Como se age sobre ela? Como ela adquire continuidade? Como é moldada em formas concentradas, firmes ou razoavelmente confiáveis? Isto é, como se produz agência? Sob que circunstâncias, em lugares e tempos particulares, a não fixidez da identidade se torna provisoriamente fixa, de tal modo que indivíduos e grupos possam se portar como uma espécie particular de agência, uma agência política ou outra? Como as pessoas - os trabalhadores - são moldadas para se tornarem sujeitos que agem, entendendo-se de formas justificadas ou possíveis ${ }^{20}$

A política é o esforço de domesticação da infinitude da identidade..$^{41}$ Ela é a tentativa de hegemonizar a identidade, de 'ordená-la' numa direção programática forte. Se a identidade é descentrada, a política é a tentativa de criar um centro. Além disso, esse impulso para a coerência, para produzir consistência e 
completude, em quaisquer que sejam as modalidades precisas, mas certamente mediante interpelações político-partidárias e outras interpelações programáticas, muitas vezes de formas simplificadas e tranquilizadoras, acarreta um trabalho simultâneo sobre a 'sociedade' - ou, para ser mais precisos, sobre os referentes sociais da identidade, sobre o sistema de sentidos e por meio do qual gerem a relação com as condições sociais e históricas de suas vidas. A política opera sobre esse campo imaginário procurando compreender como estáveis e unitárias as agregações fragmentárias, divididas e antagonísticas de relações sociais e espaços sociais que chamamos de 'sociedade'. Mais uma vez, é isso que tem de acontecer para que os indivíduos e grupos possam organizar suas relações múltiplas e complexas com o mundo numa identidade política fortemente centrada capaz de motivar a ação. Para que tal ação coletiva ocorra, a própria 'sociedade' tem de ser imaginada, visualizada como o lugar onde a identidade está limitada, como aquilo em cujo nome coisas podem ser feitas.

\section{O QUe A 'ClASSE' PERMite?}

O poder da tradição política socialista era sua capacidade de aproveitar e harmonizar as identidades populares numa ideia fortemente centrada da classe trabalhadora - isto é, construir a agência política popular em torno do discurso de classe em todas as formas materialistas clássicas (com gênero definido, especializada, nacionalmente limitada, industrial). Isso funcionou da maneira mais bem-sucedida entre a fundação de partidos socialistas no final do século XIX e a ascensão do fascismo na década de 1930, seguido por outra fase nos anos 1940, quando os socialistas e comunistas entraram em coalizões maiores da esquerda, conectando a agência política de classe com apelos democráticos mais amplos. Mas qualquer que seja o período e o lugar, os partidos socialistas sempre continham uma sociologia bem mais rica do que sugeriria um simples argumento político de classe, seja em termos de membros, eleitores, práticas ou apelo. Eles apelavam aos trabalhadores, mesmo nas mais restritas definições, de maneira altamente desigual. Também integravam segmentos muito mais amplos da população em torno do núcleo formado por trabalhadores do sexo masculino, especializados, religiosos e étnicos, quer esses eleitores cumprissem ou não os critérios para fazer parte da classe trabalhadora (por exemplo, mulheres, os não especializados, minorias nacionais) ou nem fossem da classe trabalhadora (intelectuais dissidentes, setores dos profissionais liberais, clérigos e outros funcionários de colarinho branco, donos de lojas pequenas e outros pequenos comerciantes em bairros da classe trabalhadora). Por fim, os 
partidos socialistas desenvolviam sua presença pública abrangendo uma ampla variedade de questões de 'não classe' e campos institucionais, operando por meio das retóricas públicas de cidadania democrática, justiça social e igualitarismo, assim como por meio das linguagens do socialismo em si.

Entretanto, a despeito desse ecletismo real, o centramento programático da prática socialista em torno da noção de classe é claro. Em suas lealdades automáticas - as prioridades de campanha, a sintaxe de manifestos oficiais, o senso comum retórico dos militantes - a tradição socialista era de uma consciência de classe até o âmago. Mas a concentração da identidade dessas formas tinha seus custos. Trazia uma redução para a classe. Implicava silenciamentos, exclusões e negligências. Celebrar a classe trabalhadora pressupunha denegrir e desconsiderar outras - expressar hostilidade não só para com outras classes, mas também outras categorias de trabalhadores. Marcava-se distância de quaisquer outros trabalhadores não organizados dentro dos partidos, sindicatos e maquinarias subculturais mais amplas de filiação socialista - os brutos e não respeitáveis, os criminosos, os frívolos, os sexualmente transgressivos, os devotos religiosos, os etnicamente diferentes e, naturalmente, o feminino em suas muitas encarnações possíveis. Elementos de cultura e subjetividade eram repudiados de modo semelhante - qualquer aspecto da identidade que não pudesse ser facilmente disciplinado dentro de uma noção altamente centrada de agência política de classe. É crucial que a desconsideração socialista por esse tipo de espaço político - o espaço dessas 'outras' identidades - proporcionava aberturas para que ocorressem labores contrários de persuasão e filiação, vindo do Estado, de rivais políticos, de igrejas, do entretenimento comercial etc.

Consequentemente, embora a existência da classe trabalhadora pudesse ser postulada por meio da análise da produção e de suas relações sociais, sua 'unidade' permanecia um objeto de construção nunca atingível e sempre incompleto, uma agência fictícia, uma contingência da ação política. A finalidade desse argumento - essa maneira de considerar a classe, como um projeto nunca concluído de fabricação mediante uma dialética de labor discursivo e formas e relações realmente existentes - é abrir um espaço para a política, permitir-nos entender muito melhor a popularidade variável de diferentes perspectivas políticas entre a classe trabalhadora de diferentes tempos e lugares, e em particular a dinâmica da ascensão e queda do socialismo do século XX.

Nosso argumento não deveria ser interpretado erroneamente. O terreno duramente conquistado da história social (por exemplo, estudos de família, bairro e trabalho, com seu instrumento de análise materialista de relações sociais e meios de produção) não deveria ser abandonado agora. Mas ver a 
consciência de classe como uma faculdade instável, cambiante e indeterminada aumenta a urgência da análise política e cultural - análise discursiva das 'linguagens de classe' - para mostrarmos como as capacidades de classe sociologicamente especificadas se materializaram em ação e efeitos. Como identidade coletiva, a classe pressupunha fixidezes e parcialidades de sentido que exigiam necessariamente silêncios, demarcações e exclusões para que suas solidariedades se fortalecessem e crescessem. Essas são as fronteiras que os debates contemporâneos estão revelando. Não só a teorização feminista de gênero, mas também críticas de racialização e 'brancura' e análises pós-coloniais dos efeitos metropolitanos contínuos do império nos equiparam melhor do que jamais tivemos para colocar os pés das pretensões universalizantes da análise de classe no chão. ${ }^{42}$ Aprendendo da decomposição da classe no presente, podemos produzir histórias diferentes da classe e suas valências no passado.

Temos a oportunidade de repensar o que 'classe' implica ou permite, tanto como categoria de análise social quanto como base para mobilização política. Se, como sustentamos, a identidade é móvel e não fixa, se ela não é um efeito ou reflexo das circunstâncias sociais ou da experiência social daquela antiga maneira materialista, e se a classe trabalhadora está dividida de todas as formas, sem unidade necessária em termos de consciência e experiência compartilhada, então que sentidos possíveis permanecem para a classe como categoria política operativa, capaz de mover massas de pessoas para a ação? Como ela ainda poderia ser abordada como um atributo estrutural de sociedades e como um meio essencial de compreender desigualdades de distribuição? Como poderíamos tomar a medida das críticas 'pós-modernistas' contemporâneas e juntá-las com o que é salvável e duradouro no corpus de história social existente, com suas capacidades para apreender a dinâmica da estabilidade e da mudança em contextos locais densa e intensivamente estudados?

\section{A POLÍTICA DE NOVO}

Aqui nós escolhemos uma entrada específica no debate contemporâneo, onde várias afirmações estão instabilizando o consenso que poderia ser projetado para a história social de inclinação esquerdista que emergiu das lutas anteriores por legitimação dos anos 1970 - não só a 'defesa da classe' contra 'o fim da história social', mas um conflito mais amplo de epistemologias históricas ('realistas' versus 'pós-modernistas'), discordâncias filosóficas ('política de redistribuição' versus 'política de reconhecimento'), versões de esquerda das guerras culturais, uma série de debates sobre a guinada linguística etc. ${ }^{43}$ 
Colocamos no primeiro plano o gênero e o valor da crítica feminista, mas outras contestações das suficiências materialistas da analítica mais antiga centrada em classe da história do trabalho deveriam ser acrescentadas - estando a política cultural da raça e a pós-colonialidade entre as principais delas. $\mathrm{O}$ consumo e a cultura de massas (que são, eles próprios, sempre 'baseados em gênero' e 'em raça') são uma dimensão ulterior da formação de classes no século XX, que até recentemente tanto as tradições políticas de esquerda quando a história social pós-1960 negligenciaram muito, mas que alguns estudos pioneiros estão começando a abordar, tendo os feminismos e os estudos culturais tomado a dianteira nesse sentido. ${ }^{44}$ É claro que a direita - especialmente em sua notação thatcherizada - apreendeu com sucesso a política do consumo, utilizando criativamente linguagens do individualismo, da escolha e do mercado, promovendo espalhafatosamente um consumismo expandido para abarcar tanto as exigências estruturais da economia pós-fordista quanto discursos refinados de estilo. Só recentemente a esquerda levou a sério as culturas de entretenimento de massa e seus prazeres populares, mais uma vez por iniciativa das feministas. Boa parte da política contemporânea migrou para esse terreno, um âmbito de relevância crucial para a identidade e subjetividade, talvez um lugar-chave para a nova política de classe.

Voltando-se mais uma vez para a 'perspectiva discursiva' já esboçada, não é difícil imaginar uma análise dos anos de Thatcher ou Ronald Reagan que atravessasse essas linhas, apresentando um quadro não de uma conspiração localizada em classes (que era a tentação das críticas de esquerda mais antigas), mas de um 'imaginário’ dominante, em suma hegemônico, que organizava o sentido e a representação, e criava identidades num centramento político vigoroso do tipo que descrevemos - não um centramento que banisse completamente a dissensão ou contraimpulsos (isso nunca acontece, exceto no fascismo ou em regimes inteiramente coercivos), mas que com certeza desorganizou e incapacitou as formas possíveis de resposta da esquerda. Assim a esfera da política do Estado não é simplesmente um lugar vago, e o exercício de um poder centralizado tampouco é uma ilusão. Isso restaura as esperanças de Katznelson no sentido de recuperar preocupações políticas partidárias e outras preocupações políticas formais na historiografia, mas agora sem a necessidade de separação do 'social' e com pleno reconhecimento de que os 'regimes de verdade' do governo necessitam de negociação, fluem em ambas as direções e provocam silêncios bem como resistência e contestação.

A história da produção da categoria de 'classe' está repleta de exemplos destas últimas, com certeza. No mínimo, uma contribuição vital da história 
social e do trabalho nos últimos 30 ou 40 anos foi recuperá-los em detalhes sutis e bem fundamentados. Essa historiografia não se encontra inteiramente invalidada por seus compromissos com noções de classe que concordamos não serem mais viáveis. Historiografias ricas e complexas não podem ser simplesmente obliteradas ("quase moribundas", como diz Joyce a respeito da história do trabalho britânica) por um tipo de decreto 'pós-modernista' ou outro, como se não tivessem mais importância (Joyce, 1995, p.76, nota 7). Com efeito, neste exato momento, algo chamado Trabalhismo Antigo está no próprio centro da retórica de um governo trabalhista e uma liderança político-partidária determinada a silenciar a voz social-democrata de gerações anteriores e pôr de lado os discursos através dos quais o próprio Partido Trabalhista construiu uma política da classe trabalhadora voltada para a emancipação. O Novo Trabalhismo equivale a uma manobra discursiva para criar um novo centro precisamente sobre as ruínas de seu próprio passado.

Os discursos comunitaristas do blairismo, a retórica amplamente vazia da 'modernização' e da 'equidade', junto à gambiarra da “Terceira Via”, fornecem permissão para reinventar o partido e esvaziar seu passado. O Novo Trabalhismo disse "adeus à classe trabalhadora" em todos os sentidos, apagando os “operários de produção, trabalhadores, nortistas, de mãos calejadas, de macacão sujo" de sua imaginação política. ${ }^{45}$ Ele reúne e interpela uma nova formação política, cujo código discursivo é um comunitarismo infinitamente flexível e do tipo 'senso comum'. Como disse Stuart Hall, o governo trabalhista fornece uma parte do que a esquerda poderia querer, mas "a verdade difícil parece ser que o projeto de Blair, em sua ênfase geral e seus pressupostos centrais, ainda é essencialmente formulado pelo thatcherismo e se move em terreno definido por ele" (Hall, 1998, p.14). Aqui, alguma noção da 'comunidade virtuosa' - uma nação imaginada, a Inglaterra central, os decentes e agradáveis - é invocada, cuja proteção contra requerentes de asilo, mães solteiras e beneficiários de assistência social autoriza políticas públicas tão conservadoras quanto as adotadas no auge do thatcherismo.

Introduzimos essas breves (e sem dúvida tendenciosas) observações sobre o governo Blair para salientar um aspecto. Escrevendo há alguns anos, Ira Katznelson disse que a história do trabalho e os historiadores e historiadoras do trabalho "faziam uma diferença" (Katznelson, 1994, especialmente p.7-11). Essa não era uma afirmação, pensamos nós, de que a história do trabalho era um ato político transformador, uma afirmação de que através da historiografia o mundo pudesse ser refeito. Era, antes, uma percepção - compartilhada, cremos nós, por muitas pessoas interessadas na história da classe trabalhadora 
- de que a maneira pela qual o passado é recuperado afeta as percepções do presente. Essa era a inspiração de Edward Thompson e Sheila Rowbotham, como de muitas outras pessoas na Grã-Bretanha e na América do Norte - de que um conhecimento de lutas passadas contribuía, ele próprio, para a resistência, que o passado proporcionava um embrião potencial de oposição, mesmo que fosse só por mostrar que as coisas não precisariam ser assim. Podem ser diferentes. Pode-se resistir ao poder em suas formas múltiplas, microfísicas, bem como onde ele continua a ser exercido em vastos segmentos como política pública, policiamento, legislação e força. A resistência também tem suas identidades e subjetividades - talvez plásticas, criadas involuntariamente e a caminho, sem a fixidez reflexiva que análises de classe anteriores lhes concediam, mas ocasionalmente reunidas em torno de recusas múltiplas que os 'atores de classe' de uma geração anterior certamente teriam achado familiares.

\section{AGRADECIMENTOS}

Este ensaio tem sua origem numa colaboração existente há muito tempo, mais recentemente no texto "Classes as Historical Subjects" [Classes como sujeitos históricos] que apresentamos na conferência sobre "Historical Perspectives on Class and Culture" [Perspectivas históricas sobre classe e cultura], realizada na Universidade de Portsmouth em setembro de 1993 (cf. o relato de BOYD; McWILLIAM, 1995). Ele faz parte da base para um livro sobre o mesmo tema a ser publicado pela University of Michigan Press. Embora estejamos preocupados aqui com questões gerais de teoria, política e historiografia, também somos limitados por nossas próprias especialidades primordiais, e a maior parte da exposição dirá respeito à historiografia britânica e europeia ocidental, junto a debates que estão ocorrendo na América do Norte. Mas a discussão poderia ser facilmente ampliada para contextos da África, América Latina e sul da Ásia. (Cf. especialmente COOPER, 1995; CHANDAVAKAR, 1997; e as discussões sobre estudos sobre subalternidade de PRAKASH; MALLON; COOPER, 1994.) Para a redação deste ensaio agradecemos a assessoria e inspiração intelectual de muitos amigos e amigas, particularmente Kathleen Canning, Kali Israel, Gina Morantz-Sanchez, Sonya Rose e Ron Suny. 


\section{REFERÊNCIAS}

ALCOFF, Linda. Cultural Feminism versus Post-Structuralism: The Identity Crisis in Feminist Theory. In: DIRKS; ELEY; ORTNER (Ed.), 1994, p.96-122.

APPLEBY, Joyce; HUNT, Lynn; JACOB, Margaret. Telling the Truth about History. New York: Norton, 1994.

BARON, Ava (Ed.) Work Engendered: Toward a New History of American Labor. Ithaca: Cornell University Press, 1991.

BERLANSTEIN, Leonard R. (Ed.) Rethinking Labor History: Essays on Discourse and Class Analysis. Urbana \& Chicago: University of Illinois Press, 1993.

BIAGINI, Eugenio F. Liberty, Retrenchment and Reform: Popular Liberalism in the Age of Gladstone, 1860-1880. Cambridge (UK): Cambridge University Press, 1992. .; REID, Alastair (Ed.) Currents of Radicalism: Popular Radicalism, Organized

Labour, and Party Politics in Britain, 1850-1914. Cambridge (UK): Cambridge University Press, 1991.

BIERNACKI, Richard. The Fabrication of Labor: Germany and Britain, 1640-1914. Berkeley \& Los Angeles: University of California Press, 1995.

BOCK, Gisela; THANE, Pat. (Ed.) Maternity and Gender Policies: Women and the Rise of the European Welfare States, 1880-1950s. London: Routledge, 1991.

BOYD, Kelly; McWILLIAM, Rohan. Historical Perspectives on Class and Culture. Social History, v.20, p.93-100, 1995.

BUTLER, Judith. Merely Cultural. New Left Review, London, n.227, p.33-44, 1998.

CANNADINE, David. The Rise and Fall of Class in Britain. New York: Columbia University Press, 1999.

CANNING, Kathleen. Feminist Theory after the Linguistic Turn: Historicizing Discourse and Experience. Signs, v.19, p.368-404, 1994.

. Gender and the Politics of Class Formation: Rethinking German Labor History. In: ELEY, Geoff (Ed.) Society, Culture, and the State in Germany, 1870-1930. Ann Arbor: University of Michigan Press, 1996b. p.105-141.

. German Particularities in Women's History/Gender History. Journal of Women's History, v.5, p.102-114, 1993.

. Languages of Labor and Gender: Female Factory Work in Germany, 1850-

1914. Ithaca: Cornell University Press, 1996a.

Social Body, Body Politics: Recasting the Social Question in Germany, 18751900. In: FRADER; ROSE (Ed.), 1996, p.211-237.

CARTER, Erica. Alice in the Consumer Wonderland: West German Case Studies in Gender and Consumer Culture. In: MOELLER (Ed.), 1997b, p.347-372. 
CARTER, Erica. How German Is She? Postwar West German Reconstruction and the Consuming Woman. Ann Arbor: University of Michigan Press, 1997a.

CHANDAVAKAR, Rajnarayan. The Making of the Working Class: E. P. Thompson and Indian History. History Workshop Journal, Oxford (UK), v.43, p.176-196, 1997.

CLARK, Anna. The Struggle for the Breeches: The Making of the British Working Class, 1780-1850. Berkeley: University of California Press, 1995.

CLARKE, Peter F. Electoral Sociology of Modern Britain. History, v.7, p.31-55, 1972. . Lancashire and the New Liberalism. Cambridge (UK): Cambridge University Press, 1971.

COHEN, Lizabeth. Making a New Deal: Industrial Workers in Chicago, 1919-1939. Cambridge (UK): Cambridge University Press, 1990.

COOPER, Frederick. Conflict and connection: rethinking colonial African history. American Historical Review, v.99, p.1516-1545, 1994.

. Work, Class, and Empire: An African Historian's Retrospective on E. P. Thompson. Social History, v.20, p.235-241, 1995.

CREW, David. Who's Afraid of Cultural Studies? Taking a 'Cultural Turn' in German History. In: DENHAM, Scott; KACANDES, Irene; PETROPOULOS, Jonathan (Ed.) A User's Guide to German Cultural Studies. Ann Arbor: University of Michigan Press, 1997.

CURRAN, James (Ed.) The Future of the Left. London: Polity, 1984.

DIRKS, Nicholas B.; ELEY, Geoff; ORTNER, Sherry B. Introduction. In: DIRKS; ELEY; ORTNER (Ed.) Culture/Power/History: A Reader in Contemporary Social Theory. Princeton: Princeton University Press, 1994. p.3-45.

DOWNS, Laura Lee. Review Article: Laura Tabili’s "We ask for British Justice” (1994). Social History, v.22, p.202-207, 1997.

EBBIGHAUSEN, Rolf; TIEMANN, Friedrich (Ed.) Das Ende der Arbeiterbewegung in Deutschland? Ein Diskussionsband zum sechzigsten Geburtstag von Theo Pirker. Opladen: Westdeutscher Verlag, 1984.

ELEY, Geoff. Foreword. In: LÜDTKE, Alf. (Ed.) The History of Everyday Life: Reconstructing Historical Experiences and Ways of Life. Princeton: Princeton University Press, 1995, p.vii-xiii.

Is All the World a Text? From Social History to the History of Society Two Decades Later. In: McDONALD, Terrence (Ed.) The Historic Turn in the Human Sciences. Ann Arbor: University of Michigan Press, 1996. p.193-243.

Labor History, Social History, Alltagesgechichte: Experience, Culture, and the Politics of the Everyday? A New Direction for German Social History? Journal of Modern History, v.61, p.297-343, 1989. 
ELEY, Geoff; NIELD, Keith. Why Does Social History Ignore Politics? Social History, v.5, p.249-271, 1980.

EPSTEIN, James. Radical Expression: Political Language, Ritual, and Symbol in England, 1790-1850. New York: Oxford University Press, 1994.

. Rethinking the Categories of Working-Class History. Labour/Le Travail, v.18, p.195-208, 1986.

. Understanding the Cap of Liberty: Symbolic Practice and Social Conflict in Early Nineteenth-Century England. Past and Present, n.112, p.75-118, 1989.

FOUCAULT, Michel. Power/Knowledge: Selected Interviews and Other Writings, 1972-1977. (Ed. Colin Gordon). New York: Pantheon Books, 1980.

FRADER, Laura L.; ROSE, Sonya O. (Ed.) Gender and Class in Modern Europe. Ithaca: Cornell University Press, 1996.

FRANK, Dana. Purchasing Power: Consumer Organizing, Gender, and the Seattle Labor Movement. New York: Cambridge University Press, 1994.

FRASER, Nancy. A Rejoinder to Iris Young. New Left Review, London, n.223, p.126129, 1997b.

. From Redistribution to Recognition? Dilemmas of Justice in a 'Postsocialist' Age. In: Justice Interruptus: Critical Reflections on the 'Postsocialist' Condition. New York: Routledge, 1997a. p.11-39.

. Heterosexism, Misrecognition, and Capitalism: A Response to Judith Butler. New Left Review, London, n.228, p.140-149, 1998.

GERSTLE, Gary. Working-Class Americanism: The Politics of Labor in a Textile City, 1914-1960. Cambridge (UK): Cambridge University Press, 1989.

GILROY, Paul. One Nation under a Groove: The Cultural Politics of 'Race' and Racism in Britain. In: ELEY, Geoff; SUNY, Ronald Grigor (Ed.) Becoming National: A Reader. New York \& Oxford: Oxford University Press, 1996. p.250-269.

GORDON, Linda (Ed.) Women, the State, and Welfare. Madison: Wisconsin University Press, 1990.

GORZ, André. Farewell to the Working Class. London: Pluto Press, 1982.

GRAY, Robert. Class, Politics, and Historical 'Revisionism'. Social History, v.19, p.211, 1994.

. The Deconstruction of the English Working Class. Social History, v.11, p.367, 1986.

The Factory Question and Industrial England, 1830-1860. Cambridge (UK): Cambridge University Press, 1996.

GROH, Dieter. Base Processes and the Problem of Organization: Outline of a General History Research Project. Social History, v.4, 1979, p.265-283. 
HALL, Catherine. Histories, Empires, and the Post-Colonial Moment. In: CHAMBERS, Iain; CURTI, Lidia (Ed.) The Post-Colonial Question: Common Skies, Divided Horizons. London: Routledge, 1996. p.65-77.

Re-Thinking Imperial History: The Reform Act of 1867. New Left Review, London, n.208, p.3-29, 1994.

HALL, Stuart. Ethnicity: Identity and Difference. In: ELEY, Geoff.; SUNY, Ronald G. Becoming National: A Reader. New York: Oxford Univ. Press, 1996. p.337-349. . Notes on Deconstructing 'the Popular'. In: SAMUEL, Raphael (Ed.) People's History and Socialist Theory. London: Routledge \& Kegan Paul, 1981.

. The Great Moving Nowhere Show. Marxism Today, p.9-14, Nov.-Dec. 1998. The Hard Road to Renewal: Thatcherism and the Crisis of the Left. London: Verso, 1988.

.; JACQUES, Martin (Ed.) New Times: The Changing Face of Politics in the 1990s. London: Lawrence \& Wishart, 1991.

HOBSBAWM, Eric et al. The Forward March of Labour Halted? London: New Left Books, 1981.

. Politics for a Rational Left: Political Writing 1977-1988. London: Verso; Marxism Today, 1989.

IGNATIEV, Noel. How the Irish Became White. New York: Routledge, 1995.

JESSOP, Bob. State Theory: Putting Capitalist States in Their Place. Philadelphia: Pennsylvania University Press, 1990.

JOHNSON, Richard. Edward Thompson, Eugene Genovese, and Socialist-Humanist History. History Workshop Journal, Oxford (UK), v.6, p.79-100, 1978.

JOYCE, Patrick (Ed.) The Historical Meanings of Work. Cambridge (UK): Cambridge University Press, 1989.

A People and a Class: Industrial Workers and the Social Order in Nineteenth Century England. In: BUSH, M. L. (Ed.) Social Orders and Social Classes in Europe Since 1500: Studies in Social Stratification. London: Longman, 1992. p.199-217.

. Democratic Subjects: The Self and the Social in Nineteenth-Century England. Cambridge (UK): Cambridge University Press, 1994.

. The End of Social History? Social History, v.20, p.73-91, 1995.

. Visions of the People: Industrial England and the Question of Class, 1840-

1914. Cambridge (UK): Cambridge University Press, 1991. . Work, Society, and Politics: The Culture of the Factory in Victorian England. Brighton: Harvester Press, 1980.

KATZNELSON, Ira. The 'Bourgeois' Dimension: A Provocation about Institutions, Politics, and the Future of Labor History. International Labor and Working-Class History, Cambridge (UK), v.46, p.18, 1994. 
KATZNELSON, Ira; ZOLBERG, Aristide R. (Ed.) Working-Class Formation: Nineteenth Century Patterns in Western Europe and the United States. Princeton: Princeton University Press, 1986.

KELLEY, Robin D. G. Hammer and Hoe: Alabama Communists During the Great Depression. Chapel Hill: University of North Carolina Press, 1990.

KIRK, Neville. 'Traditional' Working-Class Culture and 'the Rise of Labour': Some Preliminary Questions and Observations. Social History, v.16, p.203-216, 1991. . Class and the 'Linguistic Turn' in Chartist and Post-Chartist Historiography. In:___ (Ed.) Social Class and Marxism: Defences and Challenges. Aldershot: Scholar Press, 1996.

. In Defence of Class: A Critique of Recent Revisionist Writing upon the Nineteenth-Century English Working Class. International Review of Social History, v.32, p.2-47, 1987.

KOTKIN, Stephen. Magnetic Mountain: Stalinism as a Civilization. Berkeley: University of California Press, 1995.

KOVEN, Seth; MICHEL, Sonya (Ed.) Mothers of a New World: Maternalist Politics and the Emergence of Welfare States. London: Routledge, 1993.

LACLAU, Ernesto. Politics and Ideology in Marxist Theory. London: Verso, 1977. The Impossibility of Society. In: . New Reflections on the Revolution of Our Time. London: Verso, 1990. p.89-92.

.; MOUFFE, Chantai. Hegemony and Socialist Strategy: Towards a Radical Democratic Politics. London: Verso, 1985.

LEWIS, Earl. In Their Own Interests: Race, Class, and Power in Twentieth-Century Norfolk, Virginia. Berkeley: University of California Press, 1991.

LEWIS, Jane. The Politics of Motherhood. London: Croom Helm, 1980.

LINDENBERGER, Thomas. Strassenpolitik: Zur Sozialgeschichte der öffentlichen Ordnung in Berlin 1900 bis 1914. Bonn: Dietz Nachfolger, 1995.

LÜDTKE, Alf. The Role of State Violence in the Period of Transition to Industrial Capitalism: The Example of Prussia from 1815 to 1848. Social History, v.4, p.175221, 1979.

MALLON, Florencia E. The promisse and dilema of subaltern studies. American Historical Review, v.99, p.1491-1515, 1994.

MAYFIELD, David; THORNE, Susan. Social History and its Discontents: Gareth Stedman Jones and the Politics of Language. Social History, v.17, p.165-188, 1992.

McELLIGOTT, Anthony. Contested City: Municipal Politics and the Rise of Nazism in Altona, 1917-1937. Ann Arbor: University of Michigan Press, 1998.

MITCHELL, Timothy. The Limits of the State: Beyond Statist Approaches and their Critics. American Political Science Review, v.85, p.77-96, 1991. 
MOELLER, Robert G. (Ed.) West Germany under Construction: Politics, Society, and Culture in the Adenauer Era. Ann Arbor: University of Michigan Press, 1997. MOODY, J. Carroll; KESSLER-HARRIS, Alice (Ed.) Perspectives on American Labor History: The Problems of Synthesis. DeKalb: Northern Illinois University Press, 1990.

NOIRIEL, Gérard. The French Melting Pot: Immigration, Citizenship, and National Identity. Minneapolis: University of Minnesota Press, 1996.

NOLAN, Mary. Social Democracy and Society: Working-Class Radicalism in Düsseldorf 1890-1920. Cambridge (UK): Cambridge University Press, 1981.

OFFEN, Karen. Depopulation, Nationalism, and Feminism in Fin de Siècle France. American Historical Review, v.89, p.648-676, 1984.

PALMER, Bryan D. Descent into Discourse: The Reification of Language and the Writing of Social History. Philadelphia: Temple University Press, 1990.

PAUL, Kathleen. Whitewashing Britain: Race and Citizenship in the Postwar Era. Ithaca: Cornell University Press, 1997.

PEISS, Kathy. Cheap Amusements: Working Women and Leisure in Turn-of-the-Century New York. Philadelphia: Temple University Press, 1986.

PELLING, Henry. Origins of the Labour Party. London: Macmillan, 1954. . Social Geography of British Elections, 1885-1910. London: Macmillan, 1967. PENCE, Katherine. Schaufenster des sozialistischen Konsums: Texte der ostdeutschen 'consumer culture'. In: LÜDTKE, Alf; BECKER, Peter (Ed.) Akten. Eingaben. Schaufenster: Die DDR und ihre Texte: Erkundungen zu Herrschaft und Alltag. Berlin: Akademie Verlag, 1997. p.91-118.

PICKERING, Paul. Class Without Words: Symbolic Communication in the Chartist Movement. Past and Present, n.112, p.144-162, 1986.

POIGER, Uta G. Rock 'n' Roll, Female Sexuality, and the Cold War Battle over German Identities. In: MOELLER (Ed.), 1997, p.373-410.

PRAKASH, Gyan. Subaltern Studies as Postcolonial Criticism. American Historical Review, v.99, p.1475-1590, 1994.

REDDY, William. Money and Liberty in Modern Europe. Cambridge (UK): Cambridge University Press, 1987. 1984.

ROEDIGER, David. Race and the Working-Class Past in the United States: Multiple Identities and the Future of Labor History. International Review of Social History, v.38, p.127-143, 1993.

The Wages of Whiteness: Race and the Making of the American Working Class. London: Verso, 1991.

ROSE, Sonya O. 'Gender at Work': Sex, Class, and Industrial Capitalism. History Workshop Journal, Oxford (UK), v.21, p.113-131, 1986. 
ROSE, Sonya O. Gender and Labor History: The Nineteenth-Century Legacy. International Review of Social History, v.38, p.145-162, 1993.

. Limited Livelihoods: Gender and Class in Nineteenth-Century England. Berkeley: University of California Press, 1992.

ROSENHAFT, Eve. Beating the Fascists?: The German Communists and Political Violence 1929-1933. Cambridge (UK): Cambridge University Press, 1983.

SCHNEIDER, Michael. In Search of a 'New' Historical Subject: The End of Working-Class Culture, the Labor Movement, and the Proletariat. International Labor and Working-Class History, Cambridge (UK), v.32, p.46-58, 1987.

SCOTT, Joan W. On Language, Gender, and Working-Class History. International Labor and Working-Class History, Cambridge (UK), v.31, p.1-13, 1987.

Reply to Criticism. International Labor and Working-Class History, Cambridge (UK), v.32, p.39-45, 1987.

. Only Paradoxes to Offer: French Feminists and the Rights of Man. Cambridge (Mass.): Harvard University Press, 1996.

. The Evidence of Experience. In: The Historic Turn in the Human Sciences. Ann Arbor: University of Michigan Press, 1996. p.379-406.

. Gender: A Useful Category of Historical Analysis. American Historical Review, v.91, p.1053-1075, 1986. Reproduzido em: Gender and the Politics of History. New York: Columbia University Press, 1988. p.28-50.

SEWELL Jr., William H. Work and Revolution in France: The Language of Labor from the Old Regime to 1848. Cambridge (UK): Cambridge University Press, 1980.

A Rhetoric of Bourgeois Revolution: The Abbé Sieyes and What Is the Third Estate? Durham: Duke University Press, 1994.

SIEGELBAUM, Lewis H.; SUNY, Ronald Grigor (Ed.) Making Workers Soviet: Power, Class, and Identity. Ithaca: Cornell University Press, 1994.

SMAIL, John. New Languages for Labor and Capital: The Transformation of Discourse in the Early Years of the Industrial Revolution. Social History, v.12, p.49-72, 1987. SOMERS, Margaret R. Narrativity, Narrative Identity, and Social Action: Rethinking English Working-Class Formation. Social Science History, v.26, p.591-630, 1992.

SONENSCHER, Michael. Work and Wages: Natural Law, Politics, and the Late Eighteenth Century French Trades. Cambridge (UK): Cambridge University Press, 1989. STEDMAN JONES, Gareth. Anglo-Marxism, Neo-Marxism, and the Discursive Approach to History. In: LÜDTKE, Alf (ed.). Was bleibt von marxistischen Perspektiven in der Geschichtsforschung? Göttingen: Wallstein, 1997. p.173-182.

. Charles Fourier: The Theory of the Four Movements (no prelo).

. Languages of Class: Studies in English Working-Class History 1832-1982. Cambridge (UK): Cambridge University Press, 1983. 
STEDMAN JONES, Gareth. The Determinist Fix: Some Obstacles to the Further Development of the Linguistic Approach to History in the 1990s. History Workshop Journal, Oxford (UK), v.42, p.19-35, 1996.

STEINBERG, Marc W. 'The Labour of the Country is the Wealth of the Country': Class Identity, Consciousness, and the Role of Discourse in the Making of the English Working Class. International Labor and Working-Class History, Cambridge (UK), v.49, p.1-25, 1996.

. Culturally Speaking: Finding a Commons between Post-Structuralism and the Thompsonian Perspective. Social History, v.21, p.193-214, 1996.

SUGRUE, Thomas. The Origins of the Urban Crisis: Race and Inequality in Postwar Detroit. Princeton: Princeton University Press, 1996.

TABILI, Laura. "We Ask for British Justice": Workers and Racial Difference in Late Imperial Britain. Ithaca: Cornell University Press, 1994.

THOMPSON, Edward P. The Poverty of Theory and Other Essays. London: Merlin, 1978.

TILLY, Louise A. History's Noncrisis. International Labor and Working-Class History, Cambridge (UK), v.46, p.87, 1994.

TOURAINE, Alain. L'après socialisme. Paris: Grasset, 1983.

VERNON, James. Politics and the People: A Study in English Political Culture, c.18151867. Cambridge (UK): Cambridge University Press, 1993.

VON SALDERN, Adelheid. Auf dem Wege zum Arbeiter Reformismus: Parteialltag in sozialdemokratischer Provinz: Göttingen (1870-1920). Frankfurt am Main: Materialis, 1984.

WERTH, Paul W. Through the Prism of Prostitution: State, Society, and Power. Social History, v.19, p.1-15, 1994.

WILSON, Elizabeth. Women and the Welfare State. London, 1977; DAVIN, Anna. Imperialism and Motherhood. History Workshop Journal, Oxford (UK), v.5, p.9-65, 1978.

WRAY, Matt; NEWITZ, Annalee (Ed.) White Trash: Race and Class in America. New York: Routledge, 1997.

YOUNG, Iris Marion. Unruly Categories: A Critique of Nancy Fraser's Dual Systems Theory. New Left Review, London, n.222, p.147-160, 1997.

\section{NOTAS}

${ }^{1}$ Originalmente publicado em International Labor and Working-Class History, v.57, p.130, Apr. 2000.

2 TOURAINE, 1983; GORZ, 1982. Para o debate na Alemanha Ocidental nessa mesma época, EBBIGHAUSEN; TIEMANN (Ed.), 1984. O equivalente britânico teve início mais 
cedo, na verdade antes da eleição de Margaret Thatcher em 1979, na Marx Memorial Lecture de 1978 feita por Eric Hobsbawm. Cf. HOBSBAWM et al., 1981. Para o contexto geral desses debates, cf. SCHNEIDER, 1987.

${ }^{3} \mathrm{Na}$ Grã-Bretanha, o debate começou na revista New Socialist, um recém-estabelecido (e efêmero) periódico de discussão do Partido Trabalhista (de 1981 até que sua independência foi efetivamente terminada em meados dos anos 1980) e foi, depois, assumido pela revista teórica do Partido Comunista da Grã-Bretanha intitulada Marxism Today, que cunhou o slogan dos "Novos Tempos" e foi pioneira de um novo revisionismo de esquerda até seu término em 1991. Cf. CURRAN, 1984; HALL; JACQUES (Ed.), 1991; HOBSBAWM, 1989; HALL, 1988.

${ }^{4}$ HALL; JACQUES (Ed.), Introduction, 1991. p.11.

${ }^{5} \mathrm{O}$ número de citações possíveis aqui seria enorme. Para uma indicação, cf. HALL, 1996; GILROY, 1996.

${ }^{6}$ Cf. ROEDIGER, 1991; 1993; IGNATIEV, 1995; WRAY; NEWITZ (Ed.), 1997.

${ }^{7}$ Para a Grã-Bretanha, cf. especialmente TABILI, 1994; e para o âmbito mais amplo da cidadania, PAUL, 1997. Para uma recensão penetrante de Tabili, que esboça o contexto historiográfico geral, cf. DOWNS, 1997. Para a França, cf. NOIRIEL, 1996.

${ }^{8}$ SCOTT, 1987, com respostas de Bryan D. Plamer (p.14-23), Christine Stansell (p.24-29) e Anson Rabinbach (p.30-36); SCOTT, 1987.

${ }^{9}$ KATZNELSON; ZOLBERG (Ed.), 1986. Os editores lamentam a exclusão na nota 2.

${ }^{10}$ MOODY; KESSLER-HARRIS (Ed.), 1990, p.55-79, 217-234. Mas só 13 dos 67 participantes da conferência original (realizada na Northern Illinois University, em outubro de 1984) eram mulheres.

${ }^{11}$ BARON, 1991; FRADER; ROSE (Ed.), 1996; BERLANSTEIN, 1993. Cf. também JOYCE, 1989; e ROSE, 1993.

${ }^{12}$ CANNING, 1996a; 1996b; 1994. O desafio de Joan SCOTT foi levantado inicialmente em 1986 no periódico American Historical Review, depois reproduzido em SCOTT, 1988, p.28-50.

${ }^{13}$ JOYCE, Introduction, in: JOYCE (Ed.), 1995, p.5.

${ }^{14}$ Cf. SIEGELBAUM, 1994. A maioria dos ensaios trata de categorias específicas de trabalhadores (Heather Hogan dos metalúrgicos de São Petersburgo, Hiroaki Kuromiya dos mineiros de Donbas, Diane Koenker dos gráficos, Chris Ward dos trabalhadores do algodão, Daniel Orlovsky de trabalhadores de colarinho branco) ou de locais particulares (S. A. Smith de São Petersburgo 1905-1917, Stephen Kotkin de Magnitogorsk na década de 1930). Vários deles exploram o discurso mais amplo da identidade de classe em períodos específicos (Mark Steinberg fala sobre "os trabalhadores de vanguarda e a moralidade de classe" antes da Revolução, Gabor Rittersporn sobre as categorias cambiantes do discurso social bolchevique e Sheila Fitzpatrick sobre as relações entre trabalhadores e gerentes - estes dois últimos nos anos 1930). Um último ensaio, de Victoria E. Bonnell, afasta-se do âmbito da 
história social do volume principal para analisar "a iconografia do trabalhador na arte política soviética", mas mal e mal faz referência às dimensões de gênero do material.

${ }^{15} \mathrm{O}$ volume teve origem numa conferência realizada na Michigan State University em novembro de 1990, concebida deliberadamente em resposta a discussões em outros campos, incluindo especialmente Working-Class Formation, de Katznelson e Zolberg, e as propostas gerais de Joan Scott. Comentadores de fora do campo situaram as discussões da conferência levando isso em conta, incluindo Michael Burawoy, Kathleen Canning, Geoff Eley, David Montgomery, Sonya Rose e William Sewell Jr. Um nível extraordinariamente estimulante de discussão foi alcançado na própria conferência, que abordou questões de nacionalidade e religião, além de gênero.

${ }^{16}$ Parte do mesmo hiato entre o reconhecimento da teoria e a prática da análise detalhada está presente no mais recente livro de Joyce. Scott, Riley e outros são generosamente citados na Introdução, mas a leitura detalhada de duas vidas (Edwin Waugh e John Bright) é feita conspicuamente sem referência à dimensão de gênero. Cf. JOYCE, 1994, p.6.

${ }^{17}$ Essas citações são tiradas das p.10ss e 16 da Introdução de JOYCE (Ed.), 1995. É justo citar uma das passagens na íntegra (p.10ss): "Na historiografia liberal e na de direita, 'classe' ainda é um termo central. Quando seu marco marxista é contestado, ele, ainda assim, permanece incólume como parte do senso comum profissional. Com efeito, quanto mais a noção é questionada, mais ela parece ficar arraigada nesse senso comum. Continuam-se a escrever numerosos livros-texto e monografias em que as classes ainda são atores históricos, ainda que sem seus papéis históricos. Como adjetivo, 'classe' ainda envia milhões a marchar para cima e para baixo das páginas da história, inclusive com valores de 'classe trabalhadora', política 'de classe média' etc. Como princípio narrativo, ela dá a esses atores seus vários papéis nas resultantes histórias do passado e do presente. Talvez esteja na hora de procurar novos atores e novas narrativas?". Seu trabalho anterior (JOYCE, 1980) foi sobre paternalismo fabril. Para suas afirmações subsequentes a respeito do status superior de noções populistas de 'povo', 'cidadãos' e 'nação', cf. JOYCE, 1991; e Democratic Subjects (1994). Para uma abordagem geral útil, cf. JOYCE, 1992. Nosso comentário não deveria ser entendido como hostilidade para com teorias da narratividade como tais. O próprio Joyce as empregou com efeitos interessantes; porém, ver especialmente SOMERS, 1992.

${ }^{18}$ Todos os três estavam numa espécie de diálogo íntimo e autorreflexivo com a história social, em que tinham ocupado papéis de liderança anteriormente. Cf. STEDMAN JONES, 1983; SCOTT, 1988; SEWELL Jr., 1980. Embora fundamentalmente moldadas por categorias sociais de análise, suas obras subsequentes são histórias intelectuais em sentido formal (histórias de ideias baseadas em leituras de textos publicados). Cf. STEDMAN JONES (no prelo); SCOTT, 1996; SEWELL Jr., 1994. Stedman Jones está se ocupando com "mudanças no pensamento social e político europeu na sequência da Revolução Francesa". Cf. “Contributor's Note" (p.252) em STEDMAN JONES, 1996.

${ }^{19}$ Ao que nos consta, Stedman Jones não respondeu a críticos de seu ensaio sobre o cartismo nem aprofundou sua análise da linguagem cartista. Ele reitera seu argumento em STEDMAN JONES, 1997, o texto na íntegra do qual foi extraído STEDMAN JONES, 1996. 
${ }^{20}$ GRAY, 1986, p.367. Entre outras respostas críticas, cf. especialmente EPSTEIN, 1986; MAYFIELD; THORNE, 1992. Entre as mais importantes contribuições substanciais posteriores à intervenção de Stedman Jones, que também levam a discussão para além de seu ensaio, cf. especialmente CLARK, 1995; PICKERING, 1986; EPSTEIN, 1989; 1994; SMAIL, 1987; STEINBERG, 1996; 1996. Cf. também BIERNACKI, 1995, que propõe uma modalidade de análise cultural baseada em práticas não linguísticas.

${ }^{21}$ SCOTT, 1988, p.67. A única réplica direta de Stedman Jones a Scott, que admite com relutância a 'incompletude' de uma abordagem que deixe de fora o gênero, se reduz a acusá-la de “adesão continuada a uma noção essencialista de classe", em que uma ênfase pós-foucaultiana em relações de poder substitui a ênfase marxista nas relações de produção. Cf. STEDMAN JONES, 1997, p.177, nota 39. Essa é, com certeza, uma visão equivocada sobre o sentido do trabalho de Scott e uma distorção dos efeitos teóricos de Gender and the Politics of History.

22 VERNON, 1993, p.6. Cf. também PICKERING, 1986; EPSTEIN, 1989 e 1994. Tachar essas propostas meramente de uma nova versão do antigo economismo, em que culturas políticas são abordadas como "simplesmente espelhos da experiência social", certamente é uma redução obtusa de uma analítica complexa e imaginativa, um exemplo impressionante da demarcação epistemológica que estamos tentando transcender. Cf. STEDMAN JONES, 1997, p.181, nota 44.

${ }^{23}$ SONENSCHER, 1989; BIERNACKI, 1995; GRAY, 1996. REDDY, 1984 e 1987 foram textos transicionais importantes. Em termos mais gerais, cf. JOYCE (Ed.), 1989.

${ }^{24}$ Os projetos reunidos em BARON (Ed.), 1991, e FRADER; ROSE (Ed.), 1996, tiveram genealogias independentes de Scott durante os anos 1980. Cf. especialmente ROSE, 1986. Para trabalhos sobre o Estado de bem-estar social, cf. WILSON, 1977; DAVIN, 1978; LEWIS, 1980; OFFEN, 1984; GORDON (Ed.), 1990; BOCK; THANE (Ed.), 1991; KOVEN; MICHEL (Ed.), 1993.

${ }^{25}$ CANNING, 1993. Além do trabalho compilado em BARON (Ed.), 1991, e FRADER; ROSE (Ed.), 1996, cf. especialmente ROSE, 1992; CLARK, 1995.

${ }^{26}$ Um de nós explorou essas ideias anteriormente em ELEY, 1996; e em DIRKS; ELEY; ORTNER (Ed.), 1994, p.3-45.

${ }^{27}$ Para excelentes exposições sobre a presença do Estado dentro do social, cf. WERTH, 1994; CANNING, 1996, p.126-169; CANNING, 1996, p.211-237. Para uma teoria do Estado recente, cf. JESSOP, 1990, e MITCHELL, 1991.

${ }^{28}$ Estamos pensando aqui na raiva desproporcional provocada pelo importante artigo de JOHNSON, 1978, em que ele propôs o nome 'culturalismo' para designar as perspectivas que se derivam da obra de Thompson e Genovese.

${ }^{29}$ Realmente não conseguimos entender como Louise Tilly pôde ler nosso artigo de 1980 como se fosse primordialmente um ataque à Alltagsgeschichte ("um exame bastante estreito, mas admonitório, dos primeiros passos de jovens historiadores alemães do trabalho rumo à abordagem do 'cotidiano'”) ou uma espécie de golpe preventivo. Pelo contrário, nossa defesa da Alltagsgeschichte durante um período mais longo fala por si mesma. Por 
exemplo, ELEY, 1989; ELEY, Foreword, em 1995, p.vii-xiii, que foi a primeira tradução programática de trabalhos do alemão. Em Social History (v.4, 1979) também procuramos expor o novo trabalho em seus estágios iniciais. Veja o número especial em alemão, com artigos de LÜDTKE, p.175-221, e GROH, 265-283. A descrição de Tilly ignora as finalidades principais de nosso artigo de 1980, que sustentava a relação entre história social e política numa ampla frente da história social britânica e alemã. Cf. TILLY, 1994.

${ }^{30}$ A lista de ilustrações possíveis é obviamente muito maior do que aquilo que pode ser citado aqui, mas poderia incluir os seguintes títulos. Na história americana: COHEN, 1990; GERSTLE, 1989; LEWIS, 1991; KELLEY, 1990; SUGRUE, 1996. Na história soviética: KOTKIN, 1995. Na história britânica: CLARK, 1995; GRAY, 1996. Na história alemã, a lista poderia se estender de NOLAN, 1981; ROSENHAFT, 1983; e VON SALDERN, 1984; até CANNING, 1996; LINDENBERGER, 1995; e McELLIGOTT, 1998.

${ }^{31}$ Cf. BIAGINI; REID (Ed.), 1991. A única monografia de Pelling (em contraposição a uma série de histórias gerais do Partido Trabalhista, do Partido Comunista Britânico, dos sindicatos, dos governos trabalhistas de 1945 a 1951 e da Grã-Bretanha na Segunda Guerra Mundial) foi seu primeiro livro, Origins of the Labour Party, 1954.

32 BIAGINI; REID (Ed.), 1991, p.21. Por outro lado, o elogio de Katznelson é absurdamente enfatuado, tendo em vista a relativa magreza da obra de Pelling à parte de Origins e a obra de referência Social Geography of British Elections, 1885-1910, 1967, sua hostilidade à teoria e sua indiferença a contextos sociais: "Hoje em dia, dentro da história do trabalho, não há nenhuma obra tão completa quanto a de Pelling que leve a sério uma abordagem relacional dos vínculos entre o Estado e a classe trabalhadora através de uma análise de suas instituições consideradas no marco de um regime maior".

${ }^{33}$ Até mesmo uma lista extensa de citações só poderia arranhar a superfície da bibliografia em potencial neste caso. Poder-se-ia começar por KIRK, 1991, que contém um levantamento crítico da literatura recente até aquela época.

${ }^{34}$ Estamos pensando em LACLAU, 1977; HALL, 1981; nos ensaios em HALL, 1988, especialmente p.123-173; LACLAU; MOUFFE, 1985; e nos ensaios em STEDMAN JONES, 1983.

${ }^{35} \mathrm{O}$ argumento em favor do status e da cultura como os referenciais decisivos da política da última parte do século XIX vem do clássico artigo de CLARKE, 1972. Cf. também seu livro Lancashire and the New Liberalism, 1971.

${ }^{36}$ STEDMAN JONES, 1997, parece estar fazendo isso.

${ }^{37}$ Supomos que os leitores desta revista não precisem ser persuadidos desse aspecto básico. Ao mesmo tempo, o fato de Katznelson colocar as formas institucionais da política no primeiro plano, assim como a defesa 'pós-modernista' de Joyce e algumas afirmações recentes de Stedman Jones, levam-nos a esse território. Em particular, Katznelson recomenda como modelos os expoentes de uma história política (Biagini e Reid) que parecem estar rejeitando explicações históricas sociais como tais.

${ }^{38}$ Os principais picos de intensidade devem ser conhecidos. Eles incluem os conflitos britânicos do final dos anos 1970, que culminaram na diatribe antialthusseriana de Eduard P. 
THOMPSON intitulada The Poverty of Theory and Other Essays (1978), e encenada memoravelmente na Ruskin History Workshop em dezembro de 1979; as reações à teorização pós-estruturalista da história de gênero de Joan Scott, representadas da maneira mais feroz por PALMER, 1990; e, mais recentemente, as hostilidades em torno da defesa do pós-modernismo por parte de Patrick Joyce.

${ }^{39}$ Aqui veríamos a crítica dupla de Richard Johnson ao 'estruturalismo' e ao 'culturalismo' (e a reconcepção mais ampla da ideologia, subjetividade e identidade associada com Stuart Hall e o Centro de Estudos Culturais Contemporâneos de Birmingham), a obra Languages of Class, de Stedman Jones, e as apropriações do pós-estruturalismo por parte de Scott como os três momentos dessa trajetória. Além das referências já apresentadas, cf. especialmente SCOTT, 1996, p.379-406.

${ }^{40}$ Um bom guia para passar pelas armadilhas da teorização da identidade é cf. o agora já clássico artigo de ALCOFF, 1994.

${ }^{41}$ Essa formulação é de Laclau. Cf. especialmente LACLAU, 1990, p.89-92.

${ }^{42}$ Por outro lado, em contraposição às historiadoras e historiadores americanos, na história da classe trabalhadora da Europa ocidental a disposição para lidar com exclusões de raça ainda tem um longo caminho pela frente. No Oxford Reader sobre classe, de Joyce, qualquer discussão do império ou da raça chama a atenção por sua ausência. De igual maneira, CANNADINE, 1999, ignora completamente a importância do império, da descolonização, da imigração e da raça para a moldagem das identidades da classe trabalhadora nos séculos XIX e XX. Para contra-afirmações sucintas, cf. HALL, 1996; GILROY, 1996; HALL, 1996, p.65-77; e HALL, 1994.

${ }^{43}$ As duas primeiras expressões são tiradas de títulos de obras de Neville Kirk e Patrick Joyce, que estão entre os mais polêmicos defensores das respectivas posições. Cf. KIRK, 1987; e JOYCE, 1995. Para o 'realismo' versus o 'pós-modernismo', cf. KIRK, 1996, especialmente p.93-100, 119-126, 128 (nota 22); APPLEBY; HUNT; JACOB, 1994. Para a 'redistribuição' versus 'reconhecimento', veja o debate entre Nancy Fraser e Iris Marion Young provocado pelo texto de FRASER, 1997a, p.11-39, em YOUNG, 1997; e FRASER, 1997b, p.126-129. A exposição admiravelmente lúcida de Fraser converge com nossa própria posição política. Cf. também outro debate importante: BUTLER, 1998; e FRASER, 1998.

${ }^{44}$ Nesse ponto a história social dos Estados Unidos está muito à frente do trabalho feito na Europa. Cf. COHEN, 1990; FRANK, 1994; PEISS, 1986. O trabalho na história alemã adotou uma guinada mais na direção dos estudos culturais. Cf. CARTER, 1997a; 1997b; POIGER, 1997; e PENCE, 1997, p.91-118.

${ }^{45}$ Essa descrição é tirada de um discurso de Peter Mandelson, então secretário de Estado do Comércio e Indústria e assessor de confiança de Tony Blair, que pediu demissão em decorrência de um escândalo financeiro. Cf. Independent on Sunday, 4 out. 1998.

Artigo recebido em 30 de agosto de 2013. Aprovado em 10 de outubro de 2013. 